Departamento de Historia Universidad de Santiago de Chile

Revista de Historia Social

y de las Mentalidades

Volumen 24, $\mathrm{N}^{\circ}$ 1, 2020: 311-350

Issn On Line: 0719-4749

\title{
MÁXIMAS TRANSGRESIONES EN LAS RELACIONES AMOROSAS ENTRE BLANCOS Y NEGRAS ESCLAVAS EN EL NUEVO REINO DE GRANADA DURANTE EL PERIODO DE DOMINIO HISPÁNICO*
}

\author{
MAXIMUM TRANSGRESSIONS IN THE LOVING RELATIONS \\ BETWEEN WHITES AND BLACK SLAVES IN THE NEW \\ KINGDOM OF GRANADA DURING THE HISPANIC DOMAIN PERIOD
}

\author{
MG. ROGER PITA PICO** \\ Academia Colombiana de Historia \\ Bogotá, Colombia \\ Email: rogpitc@hotmail.com \\ Id-ORCID: 0000-0001-9937-0228
}

\begin{abstract}
RESUMEN
En tiempos del antiguo régimen español, las relaciones amorosas entre blancos y negras esclavas estuvieron signadas por la represión derivada de la cerrada y jerarquizada estructura social de aquel entonces. El presente artículo intenta abordar las máximas transgresiones ocurridas en este tipo de vínculos en el Nuevo Reino de Granada, tales como: los intentos de matrimonio, el estupro, el desafío de los curas amancebados, los vínculos entre esclavas y los hijos de sus amos, y los enredos sentimentales entre amas y esclavos, casos que bajo la mentalidad de la época eran calificados como
\end{abstract}

\begin{abstract}
In the time of the old Spanish regime, the love relations between whites and black slaves were marked by the repression derived from the closed and hierarchical social structure of that time.

The present article tries to address the maximum transgressions that occurred in this type of ties in the New Kingdom of Granada, such as: marriage attempts, rape, the challenge of priests, bonds between slaves and the children of their masters and love affairs between white women and slaves, cases that under the mentality of the time were described as a maximum breach of the social order and Christian morality, being
\end{abstract}

* $\quad$ Recibido: 2 de febrero de 2018. Aprobado: 24 de marzo de 2018.

** Artículo científico. Este trabajo corresponde a una versión complementada y corregida de una primera versión presentada por el autor el 29 de junio de 2016 en el Simposio "Libertad absoluta o servidumbre perpetua. La esclavitud en Venezuela y Nueva Granada", organizado por la Academia Nacional de la Historia de Venezuela, la Asamblea Nacional de la República Bolivariana de Venezuela y la Universidad Simón Bolívar. 
un máximo quebrantamiento del orden social y la moral cristiana, siendo desde luego objeto de mayor censura y señalamiento público.

Palabras clave: Esclavos; amos; vida afectiva; Nuevo Reino de Granada; periodo colonial of course the object of greater censorship and public pointing.

Keywords: Slaves; Masters; Affective Life; New Kingdom of Granada; Colonial Period

Cómo citar: Pita P., Roger. (2020). "Máximas transgresiones en las relaciones amorosas entre blancos y negras esclavas en el Nuevo Reino de Granada durante el periodo de dominio hispánico". Revista Historia Social y de las Mentalidades, 24(1), 311-350. DOI: 10.35588/rhsm.v24i1.4205.

\section{INTRODUCCIÓN}

En el territorio del Nuevo Reino de Granada la población esclava se asentó fundamentalmente en la Costa Caribe y en el occidente en territorios de Antioquia, Chocó y Popayán, influencia negra que dejó una impronta en la formación social y cultural de sus habitantes (Jaramillo Uribe 12). Una menor proporción se ubicó en otras zonas del interior y en la franja nororiental. En el siglo XVIII los esclavos alcanzaron su máxima presencia en territorio neogranadino, principalmente vinculados a sectores vitales de la economía, tales como la minería, la ganadería y la producción de mieles (Jaramillo Uribe 11). Según el censo levantado en 1778 , esta comunidad representaba el $7.8 \%$ del total de la población, mientras que el mestizaje se hacía más que evidente al encontrarse un $46.5 \%$ de los llamados "libres" o "gentes de varios colores". Le seguía en número la gente blanca que aglutinaba a la cuarta parte del total. Por su lado, los indios mostraban un serio descenso del cual nunca volverían a recuperarse, con un 20\% aproximadamente (Tovar, Convocatoria).

Desde sus comienzos, el régimen colonial español implantó un orden basado en una estricta organización jerárquica, en donde el amo blanco se ubicaba en la cima de esa estructura social mientras que al esclavo le deparaba una posición postrera derivada del estatus que se le tenía asignado. Específicamente, el negro fue subestimado por su origen africano y por su condición de "pieza de propiedad" sujeta a compra, venta, cambio. Su mismo color de piel le rotulaba una serie de tachas, era percibido por el hombre blanco con desprecio y constantemente se hacía referencia a él con expresiones desdeñosas. Con el paso del tiempo, ese grupo dominador mostró su afanosa preocupación por distanciarse de aquellas castas de negros e indígenas y de la amalgama de posibilidades étnicas que trajo consigo el intenso mestizaje. Conceptos tan entronizados en esa élite como el honor y la pureza de sangre necesariamente se revalidaban a partir de la negación hacia cualquier asomo o alusión a la pigmentación oscura. 
Las relaciones entre integrantes del grupo social blanco e individuos en estado de esclavitud fueron complejas y diversas, algunas de las cuales desbordaron el simple esquema de dominación. Bajo ese amplio abanico de posibilidades, se encontraron extremos que oscilaban entre roces y odios hasta manifestaciones de estima fraternal, e incluso vínculos amorosos más profundos. La concepción que el amo guardaba acerca de la esclavitud, el comportamiento del negro, el contexto social, y la clase de actividad económica reinante en cada una de las regiones, fueron algunos de los factores que pudieron incidir a la hora de moldearse el tipo de relación. Adicionalmente, esas relaciones dependían del acercamiento directo entre unos y otros. Particularmente, habría que mencionar a los esclavos que estaban al servicio personal o doméstico en casa de sus propios amos, cercanía que era susceptible de propiciar expresiones afectivas y paternalistas.

Varios pudieron ser los motivos que influyeron para que llegaran a consolidarse los lazos sentimentales entre elementos de la comunidad blanca y de la comunidad esclava sin que tampoco pueda descartarse del todo la mutua seducción que pudo emerger entre las partes. Además de algunas circunstancias demográficas y geográficas que pudieron incidir, tradicionalmente se le atribuía a la raza negra un fuerte atractivo sexual, caracterizado por la juventud, la belleza corporal y la voluptuosidad, lo que resultaba llamativo para los blancos.

El padre José Gumilla, quien estuvo de visita por América al promediar el siglo XVIII en calidad de misionero, resaltó precisamente la proclividad hacia las mujeres de ébano: "Los hombres blancos han dado muestras mayores de dicha inclinación y amor al color negro, y hoy día, en Cartagena de Indias, Mompós y otras partes se hallan españoles honrados casados (por su elección libre) con negras, muy contentos y concordes con sus mujeres" (Escalante 134). Cabe citarse acá un afamado refrán español que mostraba también la propensión de los blancos a satisfacer sus instintos sexuales: "Debajo de la manta, tanto vale la negra como la blanca" (Patiño, Historia 129). Este atractivo se concentró primero en la mujer negra pero luego, tras el irrefrenable impulso de la miscegenación, las mulatas se constituyeron en las amantes y concubinas preferidas.

Asimismo, en este tipo desigual de unión primó toda la imagen que se tenía acerca de la población esclava, la cual estaba íntimamente relacionada con su postrera ubicación en la jerarquizada estratificación social. No en vano, una de las características que más se le endilgó a los exponentes de la raza negra y mulata fue su irreprimible sexualidad (Bermúdez 78). Pero, para hacerse un juicio ponderado sobre la realidad, es necesario escudriñar las condiciones en que este grupo social negroide satisfizo su sexualidad: desequilibrio de género, relaciones esporádicas, limitaciones para conformar parejas estables incluso al 
interior de su etnia, alta movilidad laboral de los cónyuges y serios impedimentos para llevar una vida familiar, entre otras (Gutiérrez y Pineda 51).

El atractivo de la raza negra y mulata estaba inserto además en un contexto de relación histórica de dominación en donde el elemento blanco en calidad de amo podía disponer de aquella casta a su antojo. Es decir, la relación amatoria pudo también ser motivada por la obligación del esclavo(a) a obedecer por su propia condición de servidumbre y a satisfacer al dueño(a) en sus apetencias instintivas. A través de esa imposición, el amo ratificó su dominio social y racial, dicho en otros términos, su relación de poder llegó incluso a permear el espectro de lo sexual. De igual manera, tanto los esclavos como las esclavas intuyeron en este tipo de vínculo la posibilidad de escalar en el proceso de blanqueamiento. ${ }^{1}$ En una relación entre componentes étnicos disímiles, era comprensible esperar que los de baja condición buscaran relacionarse sexualmente con alguien de estatus superior como una fórmula de avance social, en procura de beneficiar también a los posibles descendientes de esa unión (Grisanti 120).

La Corona y la Iglesia fueron enfáticas en su decisión de no aprobar la mezcla entre blancos y negros, al igual que manifestaron abierta oposición frente a otras alternativas de cruces interétnicos. En ese sentido, la legislación hispánica había ya estipulado desde muy temprano la recomendación de que los negros solo debían casarse con los de su misma condición (Konetzke, Vol. I 100). Esta mentalidad reacia a cualquier escarceo amoroso que afectara el estatus ostentado por el hombre blanco dejaba entrever cómo los prejuicios sociales y raciales inherentes a la condición del esclavo tenían una gran injerencia al momento de solidificarse algún tipo de vínculo (Gutiérrez, La familia 185). De allí que los amoríos que se urdieron entre exponentes de esas dos razas fueron dadas en el contexto de la ilegitimidad mediante relaciones de hecho, por lo general ocultas, y que a la postre se convertían en fuente provocadora de conflictos y rivalidades.

Desde luego, era de esperarse que las autoridades se mostraran también implacables en su decisión de impedir las relaciones de concubinato, con lo cual se pretendía mantener la sagrada estabilidad de la unión familiar legítima (Gonzalbo 269) del elemento blanco y prevenir de la amenaza que esa miscegenación podría tener en la preservación de la cerrada estructura social de la época. En muchas partes del Nuevo Reino de Granada se alcanzaron a conocer casos de amores extralegales, amancebamientos, concubinatos, pleitos por celos y los consecuentes enfrentamientos por la súbita aparición de hijos producto de

1 Sobre este tipo de mestizaje en otras regiones de los dominios novohispanos, véase: Guzmán; Castillo 107-137. 
esos amores "prohibidos". Estas relaciones fueron objeto de especial escándalo y estigmatización, en las que no faltaron los chismes, los odios, las amenazas y toda serie de pasiones humanas.

En términos comparativos, no hay duda de que en estos encuentros proscritos entre amos y esclavas la situación se tornó mucho más complicada para ellas, pues debieron enfrentar no pocos señalamientos, reproches, promesas incumplidas, súbitos destierros y otra serie de dificultades. Desde tempranas épocas, la ley estipuló la expulsión de la mujer "pecadora" del territorio. Posteriormente, se determinó que aquella que fuera sorprendida como concubina de su propio dueño debía ser liberada (Gutiérrez, La familia 268). Aunque con menor intensidad, sobre el amo amancebado también recayeron toda clase de recriminaciones morales y castigos provenientes de la justicia terrenal y divina.

Existieron además otro tipo de alianzas sentimentales y conductas sexuales que fueron susceptibles de una mayor censura, pues eran consideradas como máximas transgresiones al orden social constituido y a la normatividad vigente ${ }^{2}$ en relación con la figura del matrimonio intraétnico, a la sexualidad vista como un complejo cultural históricamente determinado y la vida sentimental de los vasallos en el mundo hispanoamericano.

El presente artículo intenta abordar las máximas transgresiones ocurridas en este tipo de vínculos en el Nuevo Reino de Granada, como por ejemplo: los romances entre esclavas y los hijos de sus amos, los intentos de matrimonio, el desfloramiento, el desafío de los curas amancebados, y los enredos sentimentales entre amas y esclavos, casos que bajo la mentalidad de la época eran calificados como un máximo quebrantamiento del orden social y la moral cristiana, lo que los convertía en objeto de mayor censura y señalamiento público. ${ }^{3} \mathrm{En}$ este contexto, la normatividad imperante traspasaba el espacio de lo público y extendía su influencia al ámbito de lo privado. Así entonces, bajo el control ejercido simultáneamente por la Iglesia y el poder político, los preceptos morales eran incorporados en las normas y esto hacía que el pecado se convirtiera en una transgresión social (Rebolledo 100). Todo ello enmarcado en un trasfondo de marcadas diferencias en el estatus social, la condición económica y la raza de los involucrados sentimentalmente.

2 Según Foucault, norma y transgresión dependen cada uno del otro de manera mutua (146-158).

3 Resulta pertinente aclarar que estos no fueron los únicos casos de transgresiones sexuales, pues también habría que considerar otras modalidades como el rapto, la violación, el incesto y la sodomía, las cuales no serán abordadas en este artículo. Véase por ejemplo: Lavrin 63; Ericastilla y Jiménez 2-24. 
Algunos trabajos recientes en Colombia han avanzado en el intento por comprender la transgresión desde la perspectiva teórica y metodológica de la microhistoria. Uno de esos trabajos es el de Max Hering y Nelson Rojas (1521), quienes plantearon la transgresión desde dos miradas; primero como el incumplimiento de las leyes formalmente decretadas por las instituciones de gobierno tanto civil como eclesiástico $\mathrm{y}$, segundo, como una práctica acaecida en el espacio social y cultural dentro de una escala de valores ya establecida que de alguna manera influyen en la sociedad y en los individuos. Aunque algunas transgresiones tienen como propósito subvertir las relaciones de poder, para el caso que nos concierne, lo que motiva al sujeto transgresor es a pecar o infringir la norma con miras a satisfacer sus intereses sexuales y emocionales.

El análisis del tema objeto de este estudio se enmarca dentro del ámbito de la microhistoria, por cuanto esta rama de la historia social permite develar el sentir de pequeñas comunidades anónimas y brinda mejores posibilidades de comprender de una manera más realista el comportamiento humano, las conductas individuales y los entramados sociales que no han sido considerados por los paradigmas y modelos tradicionales del análisis historiográfico (González, Otra invitación 39). La microhistoria, entendida como historia-relato, permite la observación de varios estudios de casos cuyos resultados pueden ser aprovechados como modelos de análisis y como instrumentos válidos de construcción de conocimiento científico (Perera y Meriño 33); (Man 168). Son, en últimas, acercamientos a pequeña escala de hechos sucedidos a nivel local con un abordaje detallado de la documentación base, en este caso, los juicios civiles y criminales ocurridos en distintos lugares del Nuevo Reino de Granada. Así entonces, este enfoque resulta muy adecuado para el desarrollo de este artículo por cuanto permite examinar los conflictos amorosos registrados entre grupos sociales disímiles y ofrece además la posibilidad de "(...) rastrear las voces que no hablan en una sociedad y que solo salen a la luz en los momentos de ruptura y de problemática social que los incluyen" (Jaramillo Velásquez 25).

Vale aclarar que este artículo forma parte de un trabajo de investigación más amplio que adelanta el autor y que incluye aquellos expedientes relativos a líos amorosos en los cuales estuvo involucrado un individuo blanco y un integrante de la comunidad esclava. La mayoría de estos expedientes fueron consultados principalmente en el Archivo General de la Nación, así como en otros archivos documentales regionales. De un total de 94 casos recopilados en la investigación, aproximadamente una tercera parte, es decir 34 casos, hacen alusión a alguna de las cinco categorías que se han considerado como máximas transgresiones: nueve relaciones de esclavas con hijos de amos, seis intentos de matrimonio entre amos y esclavas, cuatro casos de desfloramiento, nueve curas amancebados y seis 
relaciones entre amas y esclavos. Para efectos de este artículo, se ha optado por seleccionar una muestra con aquellos casos más representativos.

En cuanto a su ubicación temporal, vale anotar que un poco más de la mitad de los expedientes aquí relatados tuvieron lugar en el siglo XVIII, centuria en la cual la población esclava alcanzó su máxima presencia demográfica en territorio neogranadino en momentos en que también se registraban los más altos índices de miscegenación. Las provincias de Antioquia, Popayán y Chocó fueron los escenarios en los que transcurrieron el mayor número de casos, marcos territoriales que coincidencialmente se caracterizaron por albergar una mayor cantidad de población esclava.

\section{LOS ROMANCES CON LOS HIJOS DE LOS AMOS}

Si resultaba escandaloso para la sociedad colonial que un amo se involucrara sentimentalmente con su esclava, mucho más censurable se tornaba la situación cuando el amante era precisamente el hijo de aquel. Todo hace pensar que no fueron extrañas este tipo de relaciones gracias a la cercanía de habitar la misma casa. Incluso, algunos ejemplos en zonas con marcada influencia esclavista como Popayán y Cartagena dan cuenta de que ocasionalmente los hijos de los amos tuvieron a las esclavas como sus iniciadoras sexuales. En vista de los convencionalismos de la época, para un joven blanco podía resultar más fácil liberar su erotismo prematrimonial con una mujer de las castas que con una de su misma condición y estatus social. La reacción ante estos romances fue variada, pues osciló entre el consentimiento y la indiferencia hasta el rechazo y la oposición total.

En ocasiones, los descendientes de esas relaciones amorosas gozaron del apoyo y la consideración de los abuelos paternos, lo cual se vio reflejado en el otorgamiento de la libertad y en otra serie de beneficios. En el testamento suscrito en 1809 por Ana María de la Cuesta, vecina de la provincia del Chocó, salieron a la luz pública los amoríos secretos de su hijo con su esclava y el resultado de esa unión:

Ítem, declaro: que habiendo muerto el citado mi hijo don Felipe intestado dejando siete piezas de esclavos con otros bienes, que como su legítima heredera recayeron a mi favor: es mi voluntad que por mis albaceas se les otorgue carta de libertad a la mulatita llamada Melchora y Rosalía, mis esclavas por ser estas hijas naturales del citado mi hijo don Felipe Pontero (Mosquera 57). 
En la parroquia de San Jerónimo, provincia de Antioquia, don José Miguel Navas había consolidado un vínculo amoroso con la mulata Teresa de propiedad de sus padres, don Matías Navas y doña María Teresa Valderrama. En 1780 el joven amante propuso a sus padres comprar la libertad de la mulata en cantidad de 150 pesos, pero en el momento no se formalizó la escritura correspondiente puesto que los progenitores pensaron que ya era pública la libertad de dicha mulata por ser de todos conocido que era la "legítima mujer" de su hijo. Al momento de fallecer don Matías y doña María Teresa, su hijo acudió en 1786 ante las autoridades exigiendo la legalización de la libertad de su amada y de sus vástagos. Ante esta pretensión, fueron llamados los hermanos legítimos de don José Miguel para indagar si había alguna oposición o si tenían algo que alegar, pero reconocieron ser conscientes de que aquel hermano había pagado por la libertad de la mulata ofreciendo incluso por encima de su justo valor, motivo por el cual no veían ningún perjuicio en la repartición de la herencia. Confesaron además sentirse "conformes y gozosos" de que la mulata Teresa hubiese salido de su estado de esclavitud. Vistas estas diligencias, el visitador de la provincia don Juan Antonio Mon y Velarde procedió a otorgar las respectivas cartas de manumisión (Archivo Histórico de Antioquia, tomo 11, legajo 31, ff. 695r-703v).

En este tipo de romances, de algún modo se les atribuía a los amos cierta responsabilidad por los extravíos amorosos de sus hijos, especialmente cuando estos eran menores de edad. En el caso que se relata a continuación puede visualizarse cómo las autoridades levantaron cargos contra el padre del amancebado por su indiferencia, y en cierta manera complacencia, ante las aventuras pasionales de su hijo.

En el sitio Sacaojal en jurisdicción de Santa Fe de Antioquia, Josef María Moreno se vio envuelto en 1785 en un juicio por mantener una relación sentimental con María Antonia, esclava de su padre Cayetano Moreno. La relación llevaba ya tres años de consumada y eran tres los partos que sumaba la esclava "con notable escándalo de los vecinos de aquel sitio". Según adujo la negra, su amante le había prometido no solo casarse con ella, sino también liberarla de la esclavitud. Tanto el hermano como el cuñado del acusado confesaron conocer el concubinato y otro de los testigos dio fe de que "(...) Josef María dormía en un cuarto y en el mismo la mulata, y que no había más de una cama, y que el que declara la sentía hablar tarde de la noche en el cuarto" (Archivo Histórico de Antioquia, Tomo 27, legajo B81 1780-1790, f. 213r).

En otra ocasión, el alcalde ordinario don Francisco Antonio Otero Cossio había pasado en compañía del cura de Sacaojal a la residencia del expresado Cayetano Moreno, censurándole la relación "prohibida" que se fraguaba en su casa, pero esta reconvención no había arrojado ningún efecto ni tampoco 
había motivado al progenitor a reprender a su hijo o a castigar a su mulata por estos hechos. En razón a estos antecedentes, se libró orden judicial para que los amancebados fueran apresados y enviados a la ciudad de Santa Fe de Antioquia, disponiéndose a manera de garantía el embargo temporal de los bienes del joven Josef María mientras se resolvía el asunto. Dentro de estos caudales intervenidos se hallaban siete reses, una yegua, un potro y una mulata llamada María Antonia.

El 6 de marzo de 1786, al momento de ser llamado el amancebado a rendir descargos, sorprendió al confesar que hacía apenas nueve días había contraído nupcias con la enunciada mulata. Reconoció haber vivido con ella por largo tiempo, pero sin ser consciente de que esto podía suscitar escándalo público. La mulata respondió en los mismos términos de su recién casado, aunque negó haber sido reconvenida por alguna autoridad a causa de su relación amorosa. Por su parte, el padre reconoció haber escuchado algunos rumores de los moradores del lugar, pero solo se había convencido cuando fue advertido por el vecino don Josef Manuel de Ossa sobre la necesidad de separar a la pareja de enamorados, pero aun así siguieron viviendo juntos bajo el mismo techo. Luego de algunos días recibió el mismo de tipo de recriminaciones por parte del alcalde Otero Cossio.

En el concepto emitido por el abogado de la Real Audiencia don Ignacio Uribe el 12 de marzo de 1786, se precisó que, aunque la pareja había legalizado su condición a través del matrimonio, de todas maneras no podía quedar impune el amancebamiento que por más de dos años escandalizó al pueblo donde residían. Por lo anterior, se recomendó conminar a Josef María al pago de 10 pesos, sanción que se impuso a manera de público escarmiento. Entre tanto, al padre de Josef María se le conminó al pago de 5 pesos y a 8 días de confinamiento con un par de grillos en la cárcel, pues estimaba el juez que no solo parecía imposible que este hombre no se hubiese percatado de la "ilícita" relación en su propia casa, sino además porque no había hecho nada para poner término a esas "ofensas a Dios" ya que ni siquiera había amonestado a su hijo. Por otro lado, se advirtió a Josef María para que en lo sucesivo se abstuviera de incurrir en delitos tan "escandalosos" y a su padre para que celara "con más eficacia y temor de Dios los pecados de su casa sin disimulo alguno". Al ser notificado de este fallo y, consciente de ser el principal responsable de este drama, Josef María se comprometió a cubrir la multa impuesta a su progenitor, debiendo además responder por los 31 pesos de los costos del proceso.

Al parecer, los casos descritos en los que quedaba en evidencia el apoyo hacia este tipo de amoríos parecen haber sido menos frecuentes que aquellos en los que se observaba una actitud hostil de los familiares del amante de la esclava. Tal oposición se vio reflejada en la intención de torpedear las aspiraciones de libertad de la mujer y de los hijos producto de la unión. 
María Lucrecia de los Reyes, oriunda de la villa de Purificación, había mantenido un romance con Ignacio Rodríguez, hijo de su amo Vicente Rodríguez. Al cabo de unos años, el fruto de aquella unión, María Brígida, acudió ante el protector de esclavos para hacer valer la libertad que en vida le había prometido su abuelo. Antes de morir, Vicente había advertido a su mujer Dominga González que al fin de sus días era su deseo que su nieta María Brígida gozara de la gracia de la libertad, para lo cual otorgó la respectiva escritura. Al querer Dominga oficializar este designio a través de su testamento, sus hijos Basilio y José se lo impidieron bajo la argucia de que esa decisión causaba detrimento a la herencia, motivo por el cual se comprometieron a que de todos modos la tendrían como libre pues la reconocían como sobrina.

Aunque los oidores recomendaron elevar este caso ante las justicias de la villa de Purificación, el protector insistió en la necesidad de ser tramitado a través de las autoridades superiores, dado el inmenso poder local desplegado por Guzmán y los hermanos Rodríguez, poder con el que seguramente quedarían anuladas las esperanzas de María Brígida en su intento por reivindicar su condición de libre. Por ello, en aras de la piedad, el protector pidió a aquel máximo órgano de poder retomar el expediente de esta mulata (Archivo General de la Nación, Tomo 4, ff. 347r-352v).

En otro caso similar a este, Eustaquia Vergara, del vecindario de la parroquia de Sopetrán, se presentó en 1807 ante el gobernador y comandante general de la provincia de Antioquia don Francisco de Ayala para reclamar su libertad y la de sus hijos Juan Nepomuceno y Josefa. Esta mulata fue habida en la relación entre su madre esclava Crisanta Miranda y don Josef María Vergara, hijo del amo de aquella don Josef Manuel de Vergara. Don Josef María se fue al valle de Osos y allí se casó con una mujer blanca de su mismo estatus, pero al cabo de unos años volvió a su casa trayendo una pequeña esclava, ofreciéndosela a su padre a cambio de la libertad de su hija Eustaquia con la intención de mantenerla "recogida", propuesta que no le fue aceptada. Uno de los hermanos legítimos del padre de Eustaquia, abusando de la confianza de don Josef Manuel, fue hasta la ciudad de Santa Fe de Antioquia y allí procedió a hipotecar el valor de la esclava y de sus dos hijos como prenda de garantía para la compra de 150 pesos en ropa al comerciante don Juan Pablo Rublas.

Eustaquia reconoció que año tras año había solicitado el amparo del procurador en este proceso, pero sin encontrar ningún apoyo en concreto y al final terminó archivándose el expediente. Con mucho esfuerzo debió esta esclava recurrir a algunos trabajos independientes con tal de conseguir con qué sufragar los gastos para el trámite de su demanda. El 14 de julio de 1809 el procurador don Andrés Avelino de Uruburu, ante la falta de atención que había tenido el caso 
de Eustaquia, exigió que se reconsiderara de nuevo la petición de esta mulata y la presentación correspondiente de pruebas y testimonios (Archivo Histórico de Antioquia, tomo 59, legajo 35, f. 167v).

Uno de los afectados por las aspiraciones de Eustaquia, don Juan Pablo Rublas, se apoyó a través de su albacea de la antigua norma que otorgaba libertad a las esclavas que se casaran con sus amos, pero negaba este beneficio a las amancebadas. Otra de las pruebas contundentes para dejar sin piso la supuesta libertad otorgada era que la mulata había sido vendida por su abuelo. La defensa de Eustaquia logró el testimonio de doña Juana Narcisa Urrego, esposa del difunto don Joseph Manuel Vergara, quien aseguró que su hijo había reconocido a la dicha mulata como hija natural, a quien se había criado con estimación y a quien su amo había expresado intención de dejarla libre, aunque "no hubo ocasión de darle carta". Asimismo se aseguró que por todos era públicamente conocida como mujer liberta.

La sentencia proferida en 1810 dictaminó que la mulata y sus hijos debían permanecer en estado de esclavitud. Al cabo de siete años, cuando los españoles habían recuperado temporalmente el poder, Eustaquia volvió a reiterar su pedimento ante las autoridades de la ciudad de Santa Fe de Antioquia, haciendo ver que su expediente se había "traspapelado" por efecto de los cambios políticos y administrativos del proceso de Independencia. La mulata suministró una pista valiosa sobre el paradero de estos papeles, pero no fue posible ubicarlos. En marzo de 1819 Eustaquia imploró a la justicia se reconociera su justo derecho a ser libre, para lo cual pidió realizar la búsqueda correspondiente con el fin de ubicar el expediente en los archivos oficiales. El síndico procurador protector de esclavos consideró justa esta solicitud y dictaminó que esta mulata no fuera molestada ni inquietada mientras se revisaba la sumaria y se resolvía de una vez por todas este asunto.

\section{EL MATRIMONIO COMO DESAFÍO}

El matrimonio en la sociedad colonial y, particularmente entre el grupo social blanco, era no solo un acontecimiento de carácter religioso sino que tenía hondas implicaciones económicas. En este contexto, las bodas eran "una alianza de fortunas, de rangos sociales, de preservación de patrimonios" (Dueñas 13). Este propósito se desvirtuaba cuando se formalizaba una unión con un individuo de las castas, es decir, de menor estatus y condición social, dada la pobreza que por lo general afectaba a estos segmentos de la sociedad.

Desde un comienzo, la Corona española había planteado sus reservas frente al matrimonio entre un hombre blanco y una negra esclava, principalmente 
porque esto implicaba que ella sería libre y esto atentaba contra la estabilidad del sistema esclavista (Gutiérrez y Pineda 191). En el siglo XVIII, durante la fase del reformismo borbónico, se incrementó tanto en España ${ }^{4}$ como en los dominios de ultramar la discriminación étnica y esto llevó a las autoridades a endurecer los controles para que los matrimonios se realizaran entre iguales, todo con tal de no transgredir las jerarquías sociales (Bermúdez 101). Por otro lado, la insurrección masiva y violenta de esclavos ocurrida en la isla de Santo Domingo en 1791 llenó de temores a las autoridades españolas y a los propietarios esclavistas tanto en España como en sus dominios de ultramar, ante lo cual la Corona decidió reafirmar su política de limpieza de sangre y el sistema de castas (Helg, "La limpieza" 158).

En medio de una creciente miscegenación que había desbordado las expectativas de las autoridades, durante el reinado de Carlos III fue promulgada en 1776 la Sanción Pragmática (Konetzke, Vol. III 406-412). El propósito era evitar a toda costa el "abuso" de contraer bodas entre desiguales. Se exigió que todos los hijos menores de 25 años debían contar con el consentimiento de sus progenitores para contraer esponsales y, aun si estaban por encima de aquella edad, debían recibir consejos y recomendaciones. A los que no acataran esta ley, perderían automáticamente su condición de herederos.

A los dos años, la Pragmática se extendió a los dominios hispanoamericanos teniendo en consideración el contexto y la complejidad social típica de estos territorios. El problema fue que los argumentos de desigualdad no se limitaron al color de piel, sino que se extendieron a otros factores diferenciadores como el origen dudoso, la ilegitimidad, la falta de honor y la pobreza. La nueva Pragmática de 1803 extendió el consentimiento matrimonial a la población de castas (Jaramillo Velásquez 70).

Justo por estos años, el obispo de Cartagena emprendió una campaña en su jurisdicción contra los frecuentes matrimonios entre desiguales, culpando de esto a los hijos de familia que se apresuraban a tomar tales decisiones sin el consentimiento paterno. El prelado pidió a la Corona la imposición de severas multas y prisión para los infractores, pues muy poco escarmiento había generado la pena de excomunión (Helg, "Sociedad y raza" 331). La sola intención de querer formalizar el sagrado vínculo con una esclava podía desencadenar escándalo y alarma entre las autoridades.

Hacia 1811 se siguió una causa criminal en la ciudad de Santa Fe de Antioquia contra Pío Cifuentes tras atribuírsele haber seducido a la esclava

$4 \quad$ Un reciente estudio realizado con base en los archivos de partidas matrimoniales de la ciudad de Cádiz en el siglo XVII y XVIII arrojó un muy bajo índice de este tipo de alianzas nupciales entre blancos y esclavas (Stella 179). 
del regidor José Rendón. Todo se complicó para Pío cuando pidió a Rendón autorización para contraer matrimonio, lo que motivó a este amo a denunciarlo por "ilícita amistad" y a pensar en la posibilidad de vender la esclava. Contra el amante recayó una orden judicial de arresto y embargo de sus cortos bienes, aunque al poco tiempo pudo salir de este encierro con la condición de que no regresara jamás a la ciudad para evitar cualquier reincidencia en sus amores vedados. Se tenían además profundas reservas sobre su comportamiento por ser hombre pobre y no tener oficio conocido.

Pío no solo desobedeció la orden de destierro, sino que además se arriesgó a regresar a la ciudad, por lo cual el juez lo puso de nuevo tras las rejas, asegurándolo con carlancas o grilletes de hierro y destinándolo al trabajo de obras públicas en una de las minas de la región. Había además serios indicios de que este amante mantenía algunos galanteos con Magdalena, madre de la negra implicada. Al momento de ser llamado a rendir su testimonio, Cifuentes confesó haber regresado porque no se le había probado delito alguno y porque tampoco se le había fijado tiempo de destierro. Alegaba además que la esclava ya se había casado, con lo cual podía disiparse cualquier sospecha en la reincidencia de sus amoríos. El abogado defensor del acusado reconoció que este hombre había pedido incautamente autorización para casarse "(...) poco advertido de la prohibición que había de contraer matrimonio en esta clase de personas" (Archivo Histórico de Antioquia, tomo 36, ff. 490r-499v).

En Santa Marta tuvo lugar una historia en la que el blanco pobre José María Fernández vio frustradas sus intenciones de casarse en 1819 con la esclava Cándida Barros. Después de verificadas las tres proclamas que anunciaban el compromiso, el cura párroco de la catedral suspendió el proceso ante el recurso interpuesto por el propio hermano del contrayente, quien alegó que la bendición de esa boda era una idea descabellada por las evidentes desigualdades de la pareja y previno al religioso sobre las "fatales consecuencias" que podían desprenderse de la unión (Romero 114).

A pesar de los obstáculos, existen evidencias de haberse celebrado algunos matrimonios como el que se registró en la ciudad de Ocaña en las postrimerías del siglo XVII cuando el capitán Antonio de Herrera, luego de haber enviudado, contrajo nupcias con su esclava Florinda (Archivo General de la Nación, tomo 5, ff. 445r-520v). Por lo general, en estas uniones los contrayentes debieron afrontar toda suerte de censuras y oposiciones, dirigidas más que todo contra la cónyuge y los descendientes de este lazo marital.

En la cláusula $7^{\mathrm{a}}$ de su testamento firmado el 17 de mayo de 1797 en la ciudad de Cartago, doña Francisca Redondo y Pelayes expresó su desconcierto 
al enterarse de que su hijo residente en tierras de la provincia del Chocó había contraído nupcias con una esclava, todo esto sin su previo aval:

Ítem., declaro que el referido mi hijo Pedro Joseph ya difunto no le llegué a dar cosa ninguna porque siempre se mantuvo desde muy niño en la provincia de Nóvita en donde murió sin volverlo a ver, y asimismo se casó según se me informó en aquel entonces, sin mi gusto, ni consentimiento, ni haberme pedido para ello licencia, con una mulata esclava que fue del señor maestro don Cristóbal Baca, vecino del Chocó y ya difunto, cuya mulata mi nuera no conozco, y según se me ha dicho disque tuvo no sé cuántos hijos en ella. Declaro así para que conste. (Archivo Histórico de Cartago, caja 26, carpeta 3, f. 4v).

Pese a que la madre manifestó su desaprobación, de todos modos alcanza a percibirse en este testimonio un sentimiento de resignación al referirse a la mulata como su nuera.

Algunas parejas amancebadas no dudaron en recurrir al matrimonio como alternativa para formalizar la relación de hecho y de esta manera librarse de los públicos señalamientos y del pertinaz asedio de la justicia. Así lo hizo en 1612 en la ciudad de Santa Fe el comerciante español Juan Paz, con el fin de que las autoridades cancelaran la orden de vender su amante esclava y además para librarla de la prisión a que había sido sometida tras ser inculpada de andar en "ilícitas juntas" (Archivo General de la Nación, tomo 54, f. 1.009r-1.011v). Un episodio similar al anterior fue el que sucedió en el sitio de Sacaojal en la provincia de Antioquia en donde sorpresivamente a finales de febrero de 1786 contrajeron nupcias Josef María Moreno y la esclava de su padre para formalizar la larga relación de concubinato que tenía escandalizado al pueblo y en máxima alerta a las autoridades civiles y eclesiásticas (Archivo Histórico de Antioquia, tomo 27, legajo B81 1780-1790, ff. 20r-21v.)

Mayores fueron las dificultades que debieron afrontar las esclavas casadas ante la ausencia definitiva de sus amos consortes. Don Juan de Vanegas, vecino del sitio de Villeta en jurisdicción de la villa de Guaduas, había contraído nupcias con su esclava de color pardo Lorenza Fernández, con quien engendró cuatro hijos: Gertrudis, Joaquín, Juan y María. Vanegas se aseguró de dejar plasmado en su testamento la decisión de declarar libre a su esposa y a sus hijos, para lo cual formalizó ante el cura Joseph Murillo la respectiva carta de ahorro y libertad.

Poco tiempo después de su deceso, los hijos de su primer matrimonio legítimo descubrieron esta carta y se negaron rotundamente a entregarla a la 
beneficiada. Ante tal circunstancia, Lorenza preparó viaje hasta Santa Fe con el fin de hacer valer su legítimo derecho ante el virrey, derecho que al final le fue otorgado a ella y a su prole. No obstante, allí no cesaron los problemas para Lorenza. Años después, en 1769, siendo alcalde ordinario de la villa de Guaduas don Simón Vanegas, uno de los hijos del primer matrimonio de don Juan de Vanegas, procedió deliberadamente a encarcelar a Lorenza manteniéndola de dos pies en el cepo y pendiente de una viga bajo los rayos inclementes del sol. No contento con esta arbitraria medida, don Simón propuso que uno de sus hermanos legítimos llevara a Lorenza y a sus pequeños hasta la jurisdicción de Muzo con el objetivo de venderlos allí como esclavos, valiéndose del hecho de que en esta distante ciudad nadie estaría enterado de la declaratoria de libertad.

Advertida de estos "malévolos" propósitos y, aprovechando la precaria seguridad de la cárcel, la joven parda huyó de allí y corrió hacia su choza. Sin perder tiempo reunió a sus cuatro hijos y con la carta de libertad en mano se internó con ellos en la montaña en busca de veredas inaccesibles para no ser aprehendida de nuevo. Por varios días permaneció allí esta familia, alimentándose de frutas silvestres y soportando los rigores del clima y de la intemperie. Percatada de que sus adversarios habían suspendido la persecución, emprendió una larga travesía de catorce días $\mathrm{y}$, tras innumerables penalidades, finalmente pudo arribar a la ciudad de Santa Fe en busca de justicia. Allí logró vivir a expensas de las limosnas que las comunidades religiosas entregaban habitualmente a los pobres.

El caso llegó a conocimiento del juez de menores de esta capital, don Pedro de Rojas Camacho, quien recomendó a la Real Audiencia amparar a Lorenza y a sus vástagos en su justo derecho de libertad, pues no se podía desconocer su condición de viuda de su amo. Se pidió encargar a otra persona distinta a don Simón para que adelantara la sumaria información y se dispuso además brindar auxilio para el sostenimiento de esta desamparada familia mientras se adelantaba el juicio.

En su dictamen, los oidores de la Real Audiencia impartieron orden a las autoridades de la villa de Guaduas para que hicieran saber al alcalde Vanegas que, so pena de 500 pesos, no podía en adelante inquietar ni molestar más a Lorenza ni a sus hijos, bajo el entendido de que ellos estaban en su legítimo derecho de gozar plenamente de su libertad. De igual modo, se le instó a que si tenía pendiente alguna demanda contra ella, la pusiera en conocimiento de una instancia superior de justicia, lo cual significaba que debía abstenerse de tomar represalias por su propia mano. Aquel mismo juez designado para esta tarea debía indagar sobre la justificación que motivó a don Simón para haber encarcelado y castigado de esa forma tan cruel a Lorenza y, asimismo, debía evaluar las pérdidas que esta mujer experimentó en sus sementeras y animales de 
cría durante su ausencia, con el fin de que fuera debidamente resarcida (Archivo General de la Nación, tomo 9, ff. 489r-493v).

En las pesquisas de archivo realizadas para la investigación de este trabajo no se detectaron casos de uniones sacramentales entre un esclavo y su ama, lo cual puede obedecer a las mayores complicaciones y reproches que generaba este tipo de vínculo dentro del marco de la sociedad patriarcal y la distancia social entre una mujer blanca y un hombre en estado de esclavitud.

\section{CASOS DE DESFLORAMIENTO}

En la sociedad colonial, la virginidad era un tema que iba más allá de la castidad y tenía hondas repercusiones en el honor familiar. La pérdida de esta calidad por fuera del vínculo marital significaba una transgresión al orden moral y normativo. Particularmente para la mujer y la familia afectada, esta situación le restaba posibilidad de formalizar matrimonio con un hombre de su misma condición étnica y social (Roncancio Parra 499).

Algunos historiadores han sido partidarios de la idea, según la cual, la virginidad no tenía una verdadera importancia para las mujeres de las castas, como sí la tuvo para las mujeres blancas de superior estatus. Cuando los implicados hacían parte de este sector dominante de la sociedad, el padre de la mujer buscó resarcir el honor mancillado obligando al agresor a casarse, pero cuando existía desigualdad racial, las autoridades no se mostraron tan implacables, exigiendo en estos casos otro tipo de compensación, como por ejemplo el pago de sanciones pecuniarias (Rodríguez 168). En los estrados judiciales se alcanzaron a conocer algunas denuncias de esclavas desfloradas, por sus amos o por otros hombres blancos, ${ }^{5}$ aunque es muy probable que la mayoría de casos se mantuvieran ocultos por el temor de estas mujeres ante las posibles retaliaciones de los perpetradores.

Tal como lo precisa la historiadora María Teresa Patiño, el estupro se tipifica como un delito sexual en el cual la víctima es una mujer virgen o doncella y el agresor, por lo general, un experimentado seductor, que actuaba con engaño o artimaña para que la mujer accediera a sus deseos sexuales (Patiño, Delitos 191). El dilema que emergía casi siempre en esta temática era comprobar

La justicia también fue implacable cuando el agresor era de la misma condición étnica de la esclava, tal como sucedió en la ciudad de Tocaima hacia el año de 1780, en que la Real Audiencia sentenció a seis años de cárcel en la construcción de las murallas de Cartagena al mulato libre Enrique de Castro por haber desflorado a la negra esclava Gertrudis de tan solo doce años de edad, cuando aquel hombre se desempeñaba como mayordomo de la hacienda Calandaima. Archivo General de la Nación, Sección Colonia, Fondo Criminales, tomo 154, ff. 638r-693v. 
si el acto íntimo podía tipificarse o no como un desfloramiento, o si se había consumado por la fuerza,${ }^{6} \mathrm{o}$ si en realidad había ocurrido bajo el consentimiento de la esclava. Aquí de nuevo el debate giraba en torno a la línea porosa entre la libre voluntad, la resignación y la lealtad propia del régimen esclavista, en donde una vez más quedaba al descubierto el alcance del dominio masculino en la sociedad colonial.

Un denominador común en estas historias fueron las promesas ofrecidas por los pretendientes con tal de acceder a sus deseos amatorios. Aunque con las mujeres blancas y mestizas fue usual la promesa de matrimonio. ${ }^{7}$ para el caso de las mujeres esclavas se utilizaron otros ofrecimientos como el otorgamiento de libertad. La entrega de prendas, joyas e incluso el patrocinio de viajes hacían parte de la variada lista de dádivas. El problema era que, una vez el amante lograba su cometido, optaba deliberadamente por negar o entorpecer estos beneficios.

En términos generales, lo que se desprende del análisis de algunos expedientes de archivo es que la casta negra concibió la entrega de la virginidad como un bien muy preciado, principio asociado con el honor en el patriarcalismo español. Mientras que en el matrimonio de la mujer blanca, la entrega de la virginidad era una primicia en el inicio de la vida marital, para la negra esclava pudo ser eventualmente una fórmula para exigir como compensación la libertad personal (Gutiérrez y Pineda 271) o lograr algún resarcimiento económico. En este tipo de circunstancias que involucraban a una esclava como víctima, el matrimonio no operó como promesa del amante blanco ni como exigencia de compensación del amo, dadas las restricciones sociales que giraban en torno a estas uniones sacramentales con una pareja en estado de esclavitud. Lo cierto es que a una esclava desflorada le podía resultar más fácil rehacer su vida sentimental con otro hombre, por lo general de su misma condición étnica, todo con tal de evitar las complicaciones ya vividas en su relación intercastal.

En aquellos casos en que era otro individuo el responsable del acto sexual, el amo solía exigirle reparaciones por esta indelicadeza, tal como solía reaccionar un padre al ver su hija "deshonrada". El capitán de infantería don Pedro de Soto Altamirano, caballero de la Orden de Santiago, acusó en 1642 en

En términos comparativos, las mujeres esclavas fueron mucho más vulnerables al abuso sexual y eso se debió en parte al estereotipo que el grupo social blanco tenía acerca de ellas como libidinosas y promiscuas, razón a la cual se aferraron los agresores para eludir su culpabilidad (Mejía Velásquez 110).

7 Según una muestra recopilada por el historiador Pablo Rodríguez para el territorio del Nuevo Reino de Granada, de 30 demandas por cumplimiento de promesa matrimonial registradas en el siglo XVIII, la tercera parte estaba relacionada con pérdida de virginidad (Rodríguez 182). 
la ciudad de Cartagena al protector de indios don Juan Carrillo de Albornoz de estar amancebado durante un año con su negra criolla Agustina. Los encuentros clandestinos tenían lugar en la casa de Soto Altamirano, para lo cual Carrillo contaba con la complicidad de la dicha Agustina y de otras negras de servicio, aprovechando que el dueño de casa estaba durmiendo o en otras ocasiones andaba de guardia en la plaza.

El amo pidió castigar ejemplarmente este "grave y atroz delito" que tenía mayores complicaciones, pues el acusado era casado y, por otro lado, le había quitado la virginidad a Agustina. Se le censuraba además el hecho de que, cuando inició su conquista amorosa, Carrillo ocupaba el cargo de alcalde ordinario en cuya condición debía más bien dar buen ejemplo y no cometer abusos de esta índole. Según confesó la esclava, Carrillo la asediaba desde cuando estaba purgando un castigo de encierro en el convento de San Agustín por orden del oidor Bernardino Beltrán de Guevara, enviándole a ella recados a través de un paje negro. En el mes de septiembre de 1641, en medio del caos causado por el levantamiento de los portugueses que residían en la ciudad, Carrillo aprovechó para entrar soterradamente en casa de Soto y tomó a la esclava desflorándola, y teniendo después con ella varios encuentros carnales.

En el juicio, el amo agraviado presentó cinco esclavos de su propiedad para que dejaran registro testimonial de lo acontecido. La mulata Gabriela confesó no haberle dicho nada en ese momento a su señor con el fin de no causar alborotos. Por su parte, la negra María relató que Agustina había recibido algunos presentes de Carrillo, entre los cuales figuraba "una saya aforrada en tafetán verde". El incriminado, quien se encontraba preso en la cárcel pública de la ciudad, atribuyó todos estos señalamientos al interés que tenía Soto de perjudicarlo con el ánimo de venganza a causa del odio que desde tiempo atrás le guardaba por no haberlo ayudado a subir al cargo de alcalde y por algunas discrepancias entre sus parientes. Pidió además que le cambiaran el sitio de reclusión, pues se hallaba en un calabozo que no correspondía a su estatus social de noble al verse forzosamente mezclado con negros esclavos y "gente común y ordinaria y en mucho número".

Debido a tantas intrigas y disputas a nivel local, el caso debió ser remitido a la Real Audiencia en la ciudad de Santa Fe, instancia que el 23 de octubre de 1642 dictó para el amancebado una pena de destierro de dos años a veinte leguas de la ciudad y el pago de una multa pecuniaria de 200 ducados de castilla. La defensa de Carrillo apeló esta decisión bajo el argumento de que el delito referido no era de naturaleza punible, por no haber pruebas contundentes de haber sido la esclava virgen al momento de tener el encuentro carnal ni que este acto se hubiese consumado por medio de la fuerza. De igual modo, esta defensa 
intentó descalificar el testimonio de los esclavos por su condición de inferioridad social. Finalmente, la Real Audiencia no atendió estas apelaciones y reconfirmó la sentencia ya proferida. Por consiguiente, Carrillo debió responder por los 91 patacones y 6 reales de las costas del proceso (Archivo General de la Nación, tomo 192, ff. 349r-560v).

En otro episodio sucedido en esa misma ciudad, Pablo Antonio Cano fue apresado desde noviembre de 1787 por orden del comisario del barrio Getsemaní a causa de haber desflorado a una zamba esclava de propiedad de Manuel Moreno. El reo se mostró en profundo desacuerdo con esta medida, pues ni el referido amo ni la esclava habían interpuesto demanda, además de que, según su criterio, el comisario adolecía de la competencia para tomar este tipo de decisiones pues solo estaba facultado para intervenir en asuntos de policía y orden público en la ciudad. Cano no tuvo empacho en reconocer el motivo real de esta situación: "(...) el ofrecimiento de libertad a la zamba bajo cuya fe me hizo dueño de su claustro virginal" (Archivo General de la Nación, tomo 217 , f. 495v). Estaba convencido de que era totalmente equivocado el cargo que se le imputaba, pena que según él podía ser librada con una fianza que estaba dispuesto a cubrir con sus bienes raíces.

El teniente gobernador desestimó las razones del sindicado y en cambio ordenó al cirujano del regimiento “(...) pasase a reconocer la zamba después de un mes de ejecutado el hecho, y explicara si efectivamente estaba corrompida, si era reciente su corrupción y si había o no tenido repetidos actos o comercio con varón" (Archivo General de la Nación, tomo 217, f. 496r). Cano calificó esta diligencia de "ociosa e indecente" por cuanto ningún cirujano podía conceptuar sobre este delicado asunto, creyendo entonces que el examen lo debía practicar una partera como era tradición y como lo recomendaban los especialistas.

El fiscal José Antonio Berrío, encargado de revisar esta sumaria, ofreció a Cano la posibilidad de salir de la prisión, pero con el compromiso de resarcir su acción. Transcurrida una semana de haber recibido este dictamen, el teniente gobernador seguía negándose a liberar de la cárcel a Cano, pues pensaba que sus argumentos carecían de todo fundamento. Ante estas circunstancias, el acusado reclamó de nuevo sus derechos ante la Real Audiencia, instancia que conminó de nuevo al teniente gobernador para que acatara cabalmente las órdenes adoptadas por el fiscal Berrío.

En la crónica que sigue a continuación, se puede advertir cómo otra de las estrategias empleadas por el amo para eludir su responsabilidad era reivindicando su buen nombre y desprestigiando la conducta de su esclava amante, poniendo en duda su reputación. 
Hacia 1791 el vecino Manuel Chinchilla había tenido relaciones íntimas con la mulata María Josefa Olaya, esclava de doña Antonia Olaya y Pedroza, arrebatándole la virginidad en la villa de Honda con la promesa de que le otorgaría la libertad y le entregaría una casa y unos pesos mientras le buscaba con quien casarse. A los pocos meses, la mujer salió embarazada, pero el hombre aplazó el cumplimiento de su palabra. Tiempo después, la mulata quedó nuevamente encinta y, ante la negativa de Chinchilla de cumplir la promesa ofrecida, fue demandado en 1795 ante la justicia ordinaria. El caso no fue atendido oportunamente por haberse presentado un relevo de funcionarios, pero la afectada insistió con vehemencia en su pedimento justificado en su buena conducta:

(...) pido que aunque soy una pobre esclava me cumpla dicho Manuel Chinchilla la palabra que me dio antes de violar mi virginidad porque como digo soy una pobre esclava, pero recogida, no callejera, porque así me han criado mis señoras (...) y ahora le insté por un papel, requiriéndole que si no tenía alma, que mirase que había Dios, y que por la suma pobreza de mis señoras me quieren vender, me responde que busque el remedio por otra parte. (Archivo General de la Nación, tomo 3, f. 1.156v).

La mulata estaba convencida de que la libertad debía extenderse a sus dos hijos y aducía además que dicho vecino contaba con el suficiente dinero para cumplir su promesa sin que esta decisión afectara mucho su patrimonio. Tras ser llamado a rendir testimonio, Chinchilla negó tener cómo comprarle la libertad a María Josefa y alegó que uno de los dos pequeños no era descendiente suyo porque no se parecía en nada a él. Para la mulata estas no eran más que "frívolas disculpas" de Chinchilla para escabullir su responsabilidad y más sabiendo de los caudales que poseía.

Ante la poca acogida que tuvo su clamor, María Josefa recurrió a la misericordia del virrey José de Ezpeleta y del arzobispo de Santa Fe don Baltazar Jaime Martínez de Compañón en busca de solución a sus demandas. Denunció el hecho de haber permanecido desinformada de las providencias dictadas en el proceso por estar las autoridades locales amangualadas con su contraparte. Chinchilla respondió a lo que denominó "falsos siniestros supuestos" de la esclava y arremetió una vez más contra ella y contra su reputación al tildarla de "(...) vagamunda y prostituta que no tiene otro ejercicio como el de andar a todas horas e instantes azotando calles, como es de notoriedad pública" (Archivo General de la Nación, tomo 3, f. 1.156v). Aducía Chinchilla que no era difícil 
entender cómo esta mujer andaba en malos pasos y en tratos "ilícitos" por cuenta de los oficios que tenía de vender flores de mano, azares de pañuelos, tabacos o lavando y planchando ropa en varias casas. Negó tajantemente haberle despojado la virginidad y haberle ofrecido redimirla de la esclavitud. Manifestó no tener mucho caudal, pues solo contaba con una pulpería y unos cortos trastajos, habiendo padecido además una quiebra económica en asuntos de negocios que le impidió responder con una deuda de 6.000 pesos contraída con el vecino don Joaquín Lazcano, 600 pesos atrasados por concepto del arriendo de su habitación, 2.000 pesos que debía a don Miguel Faustino Mier y 700 más a don José Durana. En un primer fallo, las autoridades de Honda le fijaron a Chinchilla un plazo perentorio de tres días para declarar la manumisión de su hijo. El 17 de marzo de 1796 quedó finalmente oficializada ante escribano la libertad del pequeño mulato, quien fue llevado por su propio padre.

Otro caso que arroja luces sobre la problemática del desfloramiento tuvo lugar por esos años en esta misma villa ribereña. Antonio José Escobar y Burgueño, de oficio pintor, sostuvo amores con su negra esclava Lucía, de cuya relación nació el mulato Sebastián. El padre le permitió a su hijo que trabajara en la casa del gobernador de Honda en cargar leña y otros menesteres domésticos. Sebastián se ganó rápidamente el aprecio y la confianza del gobernador, por lo cual este acudió en 1797 ante las autoridades con el fin de exigir la libertad del mulato tras argumentar que Antonio José había desflorado a la negra. Para el acusado estas no eran más que falsas imputaciones que solo pretendían denigrar de su buena conducta y honradez. Le extrañaba ver cómo en sus 30 años de vida Sebastián no había realizado ninguna reclamación, razón por la cual todo lo atribuía al interés del gobernador de contar siempre con sus servicios (Archivo General de la Nación, tomo 3, ff. 168r-175v).

Una vez los amos amancebados lograban su cometido y satisfacían sus deseos pasionales, no era extraño que buscasen la forma de apartar a sus amantes. La esclava María Bruna Álvarez, vecina de la villa de Honda, debió padecer no una sino varias persecuciones de sus amos que pretendieron acceder a sus deseos con la dádiva del ofrecimiento de la libertad, promesas que terminaron siendo incumplidas. Así por ejemplo, la intención de uno de ellos, Francisco Lanis, era ganarse su confianza con la promesa de libertad y con otro tipo de incentivos como lo era un viaje a la ciudad de Cartagena. Tras haber obtenido lo que quería, el cuestionado amo no solo incumplió el ofrecimiento, sino que aborreció a la esclava y a los pocos días expresó su interés de venderla incluso por encima del precio por el cual la había adquirido. Según confesó la afectada, esta era una táctica habitual de este hombre que solía aprovecharse de las esclavas, arrebatándoles su virginidad para después venderlas. La mujer huyó al ver que 
en aquella villa no había suficientes garantías para su causa pues, según ella, allí se encubría a los hombres blancos y por su estatus no se les castigaba como era debido. Ante la reiterada negativa de Lanis de reconocer su falta, María Bruna se mostró dispuesta a jurar ante el cura su testimonio con el fin de imprimirle mayor validez. A punta de limosnas pudo llegar hasta Santa Fe y allí presentó en enero de 1792 su queja directamente ante el virrey José de Ezpeleta (Archivo General de la Nación, tomo 4, ff. 92r-93r).

\section{LOS DESCARRÍOS AMOROSOS DE LOS CURAS}

La estructura segregadora y jerárquica con base en la coloratura de la piel se constituyó en un factor de discriminación en las funciones y trabajos en el mundo hispanoamericano. En ese orden lógico, los cargos burocráticos, las profesiones eclesiásticas y de jurisprudencia, llamados también oficios "nobles", eran reservados para los blancos limpios de sangre. Así entonces, aquellos que optaban por servir a las tareas de Dios debían llenar también unos requisitos mínimos en cuanto a estatus social y linaje, aunque con el paso del tiempo algunos mestizos accedieron a esa posibilidad.

Según el censo de 1778 efectuado en el Nuevo Reino de Granada, los integrantes del sexo masculino del estamento eclesiástico representaban aproximadamente el 2\% del total de hombres blancos (Tovar, Convocatoria 73). El clero regular se concentraba básicamente en los conventos ubicados en ciudades como Santa Fe, Tunja, Cartagena y Popayán mientras que la mayor cantidad hacía parte del clero secular dentro de los cuales los curas eran el grupo más numeroso. Los miembros de la Iglesia, en su condición de exponentes de la clase blanca dominadora, terminaron reproduciendo en la práctica el sistema esclavista, pues muchos de ellos fueron propietarios de esclavos. Fue igual de evidente la participación del clero en el movimiento del mercado esclavista. No hay que perder de vista el hecho de que las órdenes religiosas y las obras pías se sostenían en buena parte con la fuerza laboral esclava (Gutiérrez, Historia 55).

Desde los inicios de la presencia española en América, la Corona y la Iglesia plantearon la importancia de evangelizar la población esclava (Pita, "El adoctrinamiento" 795-827). Con frecuencia, el acercamiento entre los miembros del estamento eclesiástico y los esclavos se dio por cuenta del servicio doméstico o servicio personal ofrecido por estos o por efectos de las labores de evangelización.

Existen pruebas que indican que los religiosos también sucumbieron a la tentación y a las flaquezas humanas, siendo objeto desde luego de una mayor 
reprobación. Aquí la dignidad de la Iglesia quedaba en entredicho cuando algunos de sus representantes resultaban seriamente comprometidos en pleitos de concubinato no solo con mujeres negras sino también con indígenas y mestizas que por lo general estaban a su servicio, conductas estas que reñían con la figura del celibato y con los principios sacramentales que ellos mismos preconizaban. Así, era mínima la autoridad moral que les quedaba para fiscalizar esta especie de pecados entre sus feligreses. Seguramente la denuncia para las esclavas involucradas no fue una tarea fácil.

Sobre este espinoso tema ya existían precedentes normativos. En las Siete Partidas promulgadas en el siglo XIII, ya se había advertido a los clérigos de abstenerse de barraganas o mujeres "sospechosas". A los que se les comprobara haber incurrido en el pecado de lujuria, serían amonestados, removidos de sus cargos, e inhibidos para oficiar misa. La mujer implicada, entre tanto, debía ser apartada de inmediato y recluida en un monasterio de por vida (Siete Partidas 70-72).

Estos mismos términos sancionatorios fueron reiterados tres siglos después por la jerarquía eclesiástica en los albores del dominio hispánico en América. En el título VI, capítulo III de la Constitución Sinodal de 1556 expedida por fray Juan de los Barrios, arzobispo de Santa Fe, se había prevenido a los clérigos de tener en sus casas "compañías sospechosas" o cualquier trato ilícito con mujeres so pena de ser castigados con la remoción de sus oficios y el destierro del obispado (Romero 544). Esta disposición fue después renovada por el Sínodo de 1606. En el Sínodo Diocesano convocado en 1617 por el obispo de Popayán don Juan González de Mendoza, se reiteraron las reprimendas contra los curas enamoradizos (Archivo Histórico Cipriano Rodríguez Santa MaríaUniversidad de La Sabana, caja 2, carpeta 3, f. 10r).

No obstante, lo que se observa en realidad es que la Iglesia no se mostró muy empeñada en aplicar las enmiendas correspondientes, pues en no pocos casos se interesó más por ocultar o desviar los procesos (Tovar, La batalla 33). Los curas cuestionados no fueron sometidos a estos rigurosos castigos, sino a penas más moderadas como el ser conminados a ejercicios espirituales o enclaustramientos temporales. Entre tanto, fueron las esclavas amantes las que, por lo general, eran sentenciadas a destierro con el compromiso de enmendar sus pecados, debiendo además lidiar con la oposición y la animadversión de los parientes y herederos de los curas ante los beneficios que estos pudieran otorgar a sus amantes. Esto dio lugar a prolongados y enmarañados litigios que debieron ser tramitados y resueltos por las autoridades civiles. En este tipo de relaciones sentimentales llama la atención el interés empecinado de algunos curas de continuar con sus romances, así fuera clandestinamente, en un franco desafío no solo a las jerarquías eclesiásticas sino a las autoridades civiles. 
En la visita pastoral que realizara en mayo de 1623 el arzobispo Fernando Arias de Ugarte a la doctrina indígena de Moncora, en la provincia de Vélez, levantó varios cargos contra el cura Alonso Ortiz Galeano, dentro de los cuales se incluía el haber dado ocasión a que se murmurara de él por tener en su hato una mulata llamada Isabel Rodríguez. Aunque el religioso descalificó de plano esa recriminación alegando que solo visitaba sus tierras una vez al año y que precisamente para ahorrarse inconvenientes decidió sacar la mujer de allí, de todas maneras el alto jerarca lo instó a no tratarla en público ni en privado para evitar cualquier "torpeza" o suspicacia (Pacheco 75-76).

En el pueblo de Samacá, ubicado en la provincia de Tunja, empezaron a correr varios rumores, según los cuales, el cura don Josef Pompeyo y su esclava Manuela Pompeyo vivían en franco concubinato. En reacción a estos comentarios, en 1790, el provisor del arzobispado de la ciudad de Santa Fe, don Miguel Masustegui, mandó una carta al cura conminándolo a que pasara inmediatamente al convento de Santo Domingo a realizar ejercicios espirituales durante nueve días, debiendo además viajar a la capital para rendir testimonio sobre las delicadas acusaciones. Adicionalmente, la jerarquía eclesiástica le ordenó a Pompeyo expulsar de su vivienda a la esclava para que estuviera alejada al menos diez leguas del referido pueblo. Sin embargo, la sindicada permaneció escondida durante dos meses en la casa de Javier del Castillo, inmueble que estaba en arriendo, pero en realidad era propiedad del referido cura. Para mayor escándalo, Manuela no tuvo empacho en regresar a la morada de su amo y engendraron allí a una hija a la que bautizaron con el nombre de Juana Sabina.

El fallecimiento del religioso sobrevino en 1794, pero antes aseguró por vía testamentaria la libertad de su esclava. Además la incluyó dentro de la lista de herederos en compensación por la "buena voluntad" con la que lo había atendido durante 14 años, cuidándole sus enfermedades y ayudándole al acrecentamiento de su patrimonio económico, atenciones que ninguno de sus parientes le había prodigado pues siempre lo tenían en total abandono. A la hija del "ilícito" romance le dejó un total de 1.000 pesos, una casa de paja y la cama completa con colgaduras, colchones, sábanas y demás elementos.

No había pasado mucho tiempo de haber sido el cura sepultado, cuando el heredero y familiar don Joaquín Pompeyo, hombre pudiente y con bastantes influencias en la ciudad de Tunja, hizo las veces de albacea y comenzó a ocultar el caudal de la mortuoria y a dilapidarlo de manera sistemática en perjuicio de los demás legatarios a quienes no quiso entregar lo que legítimamente les correspondía. Poco tiempo después, Manuela se casó con el liberto Francisco Canelón y a través de él denunció en el año de 1800 esta sarta de irregularidades ante el corregidor de Tunja. De todo el capital, que eran aproximadamente 
20.000 pesos, el albacea había actuado con "mañocidad", pues no había inventariado todos los bienes, no citó a los demás herederos, fijó los avalúos en ínfimos precios y separó para él los mejores bienes, ocultando los libros donde el testador tenía apuntado los detalles de su patrimonio. Manuela se sentía bastante inconforme, pues solo había recibido de herencia 424 pesos y, al no encontrar eco a su denuncia, decidió recurrir a la Real Audiencia.

La defensa de don Joaquín Pompeyo alegaba que la hija de Manuela era inhábil para reclamar los bienes de herencia. Para ello, se trajeron a colación las leyes de Castilla, en su título 19 , libro $7^{\circ}$ en donde se establecía que los eclesiásticos que incurrieran en "torpezas" de inmediato fueran apartados de sus barraganas. Se citó también el título $8^{\circ}$ del libro $5^{\circ}$ que prohibía a los hijos de "tan detestable coito" adquirir bienes de sus padres, norma que según el defensor de don Joaquín debía aplicarse a "(...) las concubinas que son las que como cómplices han vulnerado y manchado con su lascivia a los ministros del altísimo" (Archivo General de la Nación, tomo 2, f. 793r). Por decreto de la Real Audiencia, se dictó orden al juez para que en un plazo no superior a tres días compeliera al albacea a que restituyera el restante de las dos hijuelas que se reclamaban.

Aun cuando fueran contundentes las pruebas sobre el romance entre un cura y su amancebada, esto no era suficiente garantía para que ella reivindicara sus derechos. La negra María Isabel Noriega Mozo, residente en la ciudad de Ocaña, acudió en 1797 ante la justicia, en su condición de "viuda, pobre y de color humilde", para que se le reconociera la herencia de su difunto hijo Juan Antonio habido con don Dionisio Noriega antes de que este se ordenara y oficiara como sacerdote en el Real de minas de Río de Oro. Varias declaraciones depuestas dieron cuenta de la acogida que el fruto de esa unión tuvo en el seno de la familia paterna. Francisco Gómez de Castro, escribano de la ciudad, comentó cómo al pequeño Juan Antonio lo "(...) criaron en la casa con regalo y decencia y libre de esclavitud" (Archivo General de la Nación, tomo 4, f. 689r). A su turno, el testigo Miguel Antonio Rizo corroboró esa protección y tutelaje: “(...) distinguido en la educación, crianza y asistencia, pues fue estimado por el padre del citado Noriega y también su hermano Juan Bauptista, en tal conformidad que cuidaron aprendióse a leer y escribir perfectamente, manteniéndolo siempre con la decencia correspondiente a un hijo legítimo" (Archivo General de la Nación, tomo 4, f. 698r). El testigo José Joaquín Trujillo dio fe de que el referido joven había vivido con su padre "no como de baja esfera sino como el mejor caballero" (Archivo General de la Nación, tomo 4, f. 688r).

Sin embargo, esta aceptación no significó automáticamente el reconocimiento legal. En efecto, la familia Noriega se empecinó en demostrar 
que el mulato era nacido de la mezcla desigual entre un hombre ilustre y una plebeya esclava, lo que a la luz de las leyes de la época correspondía a un hijo bastardo. Para reforzar esta argucia se puso de relieve la estirpe española de los apellidos paternos Noriega, Zuleta y Azuero, procedentes de las ciudades de Sevilla y Burgos. Les parecía además sospechoso el hecho de que en los diez años siguientes a la muerte del cura, la negra no hubiese reclamado la libertad de su hijo y ahora sí se aparecía no solo con tal exigencia sino aspirando también a una participación en el repartimiento de la herencia.

Por su parte, la madre amparada en su condición de viuda y pobre, se mantuvo indeclinable en su pretensión de lograr que se ratificara a Juan Antonio como hijo natural, condición que lo convertía en beneficiario de los crecidos caudales dejados por el presbítero. Para ello, solicitó se ponderara la vigencia de una carta de libertad que el mismo don Dionisio le había suscrito en Río de Oro y que al parecer había sido ocultada malintencionadamente por el hermano de este. La negra confesó estar cansada de este prolongado litigio que llevaba más de dos años sin ser resuelto, viéndose además obligada a realizar seis viajes hasta la ciudad de Santa Fe. En consecuencia, solicitó que ahora sí se tuvieran en cuenta los documentos que no había podido conseguir a tiempo por su evidente estado de penuria económica, acervo probatorio que por cierto no quiso admitir el juez de Ocaña por mantener nexos con la parte contraria. Exigió además a las máximas instancias de justicia de Santa Fe garantizar la imparcialidad en este proceso e investigar las deshonestas diligencias y actuaciones del albacea don Lucas Noriega Vivanco y de los jueces de Ocaña.

Cabe precisar que los progenitores del cura le habían garantizado a María Isabel promesa de libertad a cambio de que accediera a contraer nupcias con un negro de nombre Josef, estratagema muy usual para cubrir el escándalo derivado de este tipo de unión desigual. Le impusieron además la condición de tener que parir cinco hijos. Esto, a criterio del procurador general en calidad de protector de esclavos, don Andrés Josef de Iriarte, era un flagrante abuso que había que castigar ejemplarmente, pues era "ponerlas a hacer ganancia con sus cuerpos". $\mathrm{Al}$ igual que era reprochable el hecho de que el padre del cura había consentido en su casa que su hijo abusara de la esclava en aquel "comercio criminal". Al final, el procurador no pudo conseguir que su defendida entrara a participar en las pertenencias dejadas por el religioso, aunque no obstante logró que se le adjudicara la libertad y la de dos de sus cinco hijos, para que con sus trabajos la socorrieran por su avanzada edad. Adicionalmente, se le entregó a esta mujer un auxilio de 150 pesos.

Al cura Benedicto Salgar se le acusó en 1808 de haber raptado a la esclava negra María Engracia de propiedad de doña María Josefa Rey, avecindada de la 
ciudad de Santa Fe. Según los testimonios, él la había "sacado furtivamente" de su casa y se aprovechaba de su fuero para no responder a las imputaciones que se le formulaban. La denunciante solo esperaba que las leyes eclesiásticas se aplicaran con toda severidad en este religioso sindicado además de haber quitado la virginidad a la esclava. Aunque el sacerdote quiso arreglar verbalmente el lío, doña María Josefa insistía en exigir que él dejara de asediar a la esclava y cesara su "ilícita amistad" con ella. Salgar había vendido una casa y se la había donado a los hijos que tenía con su amante.

El juez eclesiástico encargado del caso quiso dirimir esta "contienda escandalosa de un modo amigable y privado", pero el cura "no convino en este arbitrio prudente y digno del decoro de la Iglesia" (Archivo General de la Nación, tomo 9, ff. 383r-388r). Sorpresivamente, mientras doña María Josefa elevaba su demanda, al mismo tiempo el cura interponía otra, según ella, para evitar que actuara contra él y desviar la atención hacia asuntos triviales. La propietaria solo esperaba que se le restituyera su esclava que era prácticamente su único capital, pues se declaró en estado de pobreza.

A los pocos días, la autoridad competente ordenó a doña María Josefa aceptar del cura el pago por la libertad de la negra, para lo cual se practicó el respectivo avalúo. No obstante, la dueña seguía desconfiando de las intenciones del cura y por ello, a través de su abogado, aceptó la liberación de la esclava, pero con el compromiso de que esta mujer contrajera matrimonio en poco tiempo con un pretendiente de su misma condición étnica o de lo contrario saliera de Santa Fe y fuera desterrada a la ciudad de Girón de donde era oriunda, quedando el cura obligado a cubrir lo que le correspondía por concepto del viaje y la pensión de alimentación de los pequeños (Archivo General de la Nación, tomo 9, ff. 383r-388r).

\section{ROMANCES ENTRE AMAS Y ESCLAVOS}

Tal como algunos hombres blancos centraron su interés amatorio en las mujeres de raza negra, asimismo fue posible encontrar algunas blancas que fijaron su gusto en negros y mulatos de servicio. Sobre este particular, vale mencionar al joven viajero francés Gaspard-Théodore Möllien, quien a su paso por la ciudad de Santa Fe observó que "(...) las señoras blancas no tenían ninguna prevención por el color de sus criados, y se dice que hasta no los ven con indiferencia" (227).

La monótona vida parroquial, el desgaste de la relación marital, las incompatibilidades de personalidad, los descuidos afectivos, las prolongadas ausencias de los maridos, la necesidad sentimental de las mujeres o la temprana 
viudez, pudieron también ser factores que motivaron a las mujeres a buscar aventuras extramaritales. Desde luego, la situación adquiría un cariz más complejo cuando los involucrados eran una ama y su esclavo. En el Archivo Central del Cauca reposa un revelador documento mediante el cual el 31 de octubre de 1776, en la ciudad de Popayán, la señora Francisca Javiera Mejía declaró la libertad del mulato Pedro, según ella, por "haberle servido desde los trece años, haciendo los oficios de padre y marido" (Jiménez 124).

No obstante, hay que reconocer que, ya fuera secreta o públicamente, la unión ilícita entre una blanca y su esclavo fue menos habitual que aquella en la cual se involucraba un blanco y una esclava (Saco 50) debido a la mayor represión por parte de las autoridades civiles y eclesiásticas. Allí el desliz o pecado era considerado más grave por la moral imperante ya que, aparte de la relación de adulterio, se transgredía la jerarquía patriarcal. El adulterio se perseguía con más intensidad cuando era cometido por una mujer y eso se debía a que violentaba el orden moral en la medida en que se transgredía la visión cristiana y el ideal mariano que se construyó en torno a ella (Mejía Espinosa 55). En este caso se acentuó el control de la comunidad sobre la conducta individual femenina, siendo muy común el chisme y las murmuraciones (Patiño, Las mujeres 82-83).

Desde muy tempranas épocas, la legislación civil y eclesiástica había establecido sanciones para las adúlteras. ${ }^{8}$ En las Siete Partidas se fijaron severas penas para estas mujeres, como los azotes públicos y el encierro en algún monasterio, además de lo cual perdían la dote y las arras que debían pasar a manos del marido traicionado. Si este decidía perdonarla, podía a los dos años sacarla del enclaustramiento y restablecer con ella la vida conyugal (Siete Partidas 354). Por lo general, el marido traicionado era el único que podía acusar a su mujer por el adulterio cometido. Esto en vista de que el delito era tipificado como un asunto propio del ámbito privado en donde el más afectado era el esposo mismo (Jaramillo Velásquez 164).

Es muy probable que algunos casos no salieran a la palestra pública precisamente por el temor que infundía el estrecho control ejercido y por el valor mismo que las instituciones concedían a la fidelidad marital y a la castidad prematrimonial de la mujer (Gutiérrez y Pineda 272-273). La indelicadeza de la blanca era vista como una afrenta al honor del esposo legítimo y del hogar constituido. El honor masculino estaba ligado a la reputación pública y era heredado de generación en generación a través de matrimonios y nacimientos legítimos (Twinam 138).

8 Sobre el adulterio en la antigua legislación hispánica, véase: Tieghi 78-82. 
En este contexto, el poder seductor que se le atribuía al hombre negro o mulato fue severamente reprimido por el blanco, haciendo énfasis en que aquel era bastante inferior a este como para acceder en igualdad de condiciones a la mujer blanca (Wade 299). Ante el innegable dominio masculino en la vida conyugal de la época y el carácter sumiso del género femenino dentro del marco de la sociedad patriarcal, no fue difícil entender la reacción de un amo que actuara con firmeza y venganza contra cualquier esclavo que osara entablar algún romance con su esposa.

En la siguiente crónica se pueden visualizar no solo las hondas implicaciones de este tipo de vínculos sino también las represalias violentas que pudieron suscitarse en el esposo traicionado. El hecho tuvo lugar en jurisdicción de la ciudad de Girón cuando solo habían transcurrido algunos cuantos años del siglo XIX. Allí, don Andrés Ordóñez azotó cruelmente y le mutiló las orejas a su mulato esclavo Bernabé por presumir que este sostenía relaciones clandestinas con su señora. Al ser llamado a descargos, Ordóñez relató con juiciosa minucia el episodio que lo llevó a cometer tan desmesurado maltrato. Desde hacía un mes ya tenía serias sospechas por las inusuales muestras de "recíproco cariño" que observaba entre su esposa y el esclavo, razón por la cual se mantuvo en alerta vigilando los movimientos de ambos. Una de esas noches sus temores parecieron convertirse en realidad, pues vio cómo el mulato salió de su habitación y se dirigió sigilosamente a la de ella. Al percatarse el esclavo de que estaba siendo espiado, trató de retroceder, pero se tropezó con Ordóñez, quien de inmediato lo amarró, lo encerró y lo presionó para que confesara cuál era su verdadera intención. Bernabé señaló a su señora de ser ella la que horas antes lo había persuadido y citado en reiteradas ocasiones para hacer "cosas torpes" por la noche.

Convencido de la infidelidad de su mujer y, temeroso del escándalo que podía generar este desliz, procedió entonces a castigar a Bernabé con azote y a cometer la crueldad de cortarle a su servidor las orejas. Cuando llevaba más de quince días padeciendo estas torturas, como pudo el esclavo rompió la ventana de la habitación donde se hallaba confinado y escapó. El criado de don Ramón Rey lo encontró cuando transitaba desesperado por uno de los caminos de esa jurisdicción y pudo comprobar que llevaba hinchada la cabeza por cuenta de las heridas causadas en las orejas y además de esto observó que llevaba todo el cuerpo "muy verde y acardenalado" de tanto rejo que su señor le había propinado. Aunque el mulato no reveló en este encuentro el motivo real del castigo, le reiteró a aquel criado que su firme intención era no volver donde su amo ante el temor de que este lo asesinara tras haberse fugado de la casa.

Ante estos insucesos, el propio Ordóñez le propuso a su esclavo liberarlo a cambio de que se fuera lejos de la provincia, puesto que jamás quería ver a un 
hombre que había manchado su honra y perturbado la tranquilidad de una unión familiar de más de dieciséis años. El indignado amo renovó esta propuesta ante la justicia bajo la condición de que se guardara absoluta reserva para evitar el escándalo y el público descrédito que podría desencadenar el desarrollo de un juicio formal.

Al cabo de unos cuantos días, inadvertidamente el esclavo se presentó de rodillas ante su dueño y ante los tribunales para retractarse de lo dicho. Confesó no haber tenido nunca "trato ilícito" con su ama y que ninguno de los dos lo había siquiera intentado. Juró además que el malentendido consistió en que quería salir al patio y por estar medio dormido entró equivocadamente al aposento donde ella estaba acostada. La causa que expuso el mutilado Bernabé de haber rendido la primera versión fue por estar bajo presión y temeroso de que el exaltado amo lo asesinara si no le contestaba de inmediato y que, en conclusión, aquella declaración había sido apresurada e infundada, pues en realidad su señora jamás había intentado propuesta indecente alguna.

En realidad, era tan excepcional este tipo de relación prohibida que las autoridades judiciales de Girón debieron enviar el expediente a la ciudad de Santa Fe para que fuera la Real Audiencia la que adelantara el juicio e impusiera los castigos correspondientes. El mismo esposo agraviado reconoció que este era un "caso raro y no determinado ni previsto por las leyes". El fiscal de lo civil don Diego Frías se abstuvo de pronunciarse y creyó prudente enviar primero el caso al protector de esclavos, pues en este litigio estaban en juego los derechos de Bernabé ante el maltrato de su señor y el ofrecimiento de libertad que este le había formulado.

Don José Gregorio Gutiérrez, el protector designado para estudiar este litigio, reconoció la crueldad, sevicia e inhumanidad con que había actuado Ordóñez, transgrediendo con ello las cédulas reales que recomendaban a los amos brindar buen trato a sus servidores. No obstante, este funcionario se abstuvo de fijarle la pena a este agresor por considerar que era un asunto de exclusiva competencia del fiscal y porque además en medio de este lío estaba en juego un asunto tan delicado, como lo era la paz y tranquilidad del matrimonio del amo. En conclusión, Gutiérrez solo se redujo a pronunciarse sobre el esclavo, por lo cual solicitó a la Real Audiencia que Ordóñez cumpliera inmediatamente con el ofrecimiento de la carta de libertad "para que sirva en alguna manera de compensación a la gravísima injuria" cometida.

Frías reaccionó cuestionando seriamente el concepto del protector de esclavos por cuanto consideraba que no estaba cumpliendo con los deberes de su cargo y porque no podía desentenderse de la acción criminal y remitirse simplemente al pronunciamiento del fiscal. Según adujo este funcionario, 
Gutiérrez no podía escudarse en el pretexto de la tranquilidad y honor de los amos para encubrir toda suerte de crueldades. Pidió entonces a la Real Audiencia que en su dictamen procediera criminalmente contra Ordóñez.

Finalmente, la sala de oidores reunida el 22 de julio condenó al amo agresor a que expidiera de manera inmediata escritura de libertad a su esclavo, entregándole además 50 pesos para ayuda de sus viáticos. De igual manera, se le condenó a una multa de 100 pesos para responder por los gastos del proceso. Entre tanto, Bernabé fue conminado a salir inmediatamente de la ciudad de Girón, siendo desterrado al sitio que designara el alcalde ordinario. El 21 de octubre Ordóñez envió a Santa Fe el pago de la multa y adicional a esto los 18 pesos y 4 reales de las costas del proceso (Archivo General de la Nación, tomo 4, f. 801r).

En esta crónica es posible advertir la honda repercusión moral que implicaba la sola murmuración de amoríos entre una señora y su esclavo. Las notorias diferencias sociales entre unos y otros, derivadas de las disímiles condiciones étnicas, ejercían su influjo para que se hiciera todo lo posible con tal de evitar que el honor del amo blanco fuera vulnerado y mancillado. Aunque todo indicaba que era innegable el extravío amoroso entre Bernabé y su ama, estaban de por medio los fuertes convencionalismos parroquiales con una línea poco visible entre lo público y lo privado. El repudio por los vínculos entre un esclavo y una mujer blanca no solo provino de parte del esposo blanco agraviado, sino paradójicamente también de los familiares de la amante, quienes a pesar de la cercanía filial no dudaron en manifestar toda suerte de cuestionamientos morales en aras de la preservación del honor y del buen nombre.

Hacia el año de 1800 en el barrio La Aguacatala de la villa de Medellín, el esclavo mulato Ramón Jaramillo y la blanca pobre Francisca Montoya fueron arrestados por supuesto amancebamiento y escándalo público. Este fue el testimonio suministrado por una de las vecinas del lugar:

(...) que le consta que Ramón Jaramillo, esclavo de doña Ana María Jaramillo, tanto en el día como en la noche asiste en la casa de estas (Francisca y su madre) con músicas, cantos y rochelas, con escándalo público de todos los vecinos, y quedándose a dormir en la casa y llevándoles y trayéndola a fandangos a deshoras de la noche públicamente; y con todo gusto de la madre y con acciones escandalosas. (Archivo Histórico Judicial de Medellín, caja 138, documento 2.857 , f. $4 \mathrm{v})$.

Al ser interrogada, Francisca rechazó las acusaciones y, aunque reconoció que el joven mulato entraba regularmente a su morada, negó haberlo tratado 
como si fuera su marido. Estas asiduas visitas se debían a la amistad que el esclavo sostenía desde hacía bastante tiempo con un hermano de ella, con quien solía divertirse cantando y tocando vihuela, pero aclaró que en ningún momento tenían lugar allí rochelas u otro tipo de desórdenes. Aceptó, sin embargo, haber estado en compañía del esclavo en dos bailes, pero sin llegar a provocar escándalos. Negó que el mulato le hubiese entregado algún regalo ni que tampoco la mantuviera económicamente, solo en una ocasión él tuvo el detalle de obsequiarle un pañuelo de seda.

El expediente fue remitido al fiscal Rafael Naranjo, quien dictaminó que Francisca debía ser desterrada y, en relación con el esclavo Ramón, se dispuso que fuera entregado a su ama para que lo vigilara más de cerca. El abogado defensor de la sindicada alegó que no podía aplicársele a ella esta pena pues, aunque se reconoció que era pobre, eso no significaba necesariamente que fuera vaga, pues era reconocida por muchos como una mujer "recogida y decente", sin ninguna tacha ni antecedente judicial, dedicada a buscar alternativas de supervivencia como hilandera. En el fallo final se decidió librar a Francisca de la prisión con el compromiso de evitar cualquier trato o comunicación con su presunto amante. Por su condición de pobreza, fue exonerada del pago de fianzas y de las costas del proceso judicial.

Tres años más tarde se siguió en esta misma provincia de Antioquia una causa criminal contra la viuda doña María Antonia Galván, acusada por su propio hermano don Ventura de vivir en "ilícita amistad" con su esclavo Salvador del Rosario. Esta mujer viuda de aproximadamente 50 años de edad declaró ser "de calidad blanca" y dedicada a las rocerías y labranzas en su natal pueblo de Sopetrán. Según se dedujo de los siete testimonios allegados por el demandante, la relación llevaba ya más de seis meses de haberse iniciado, viéndoseles unidos por todas partes, almorzando y cenando en el mismo plato, bañándose juntos en la quebrada y durmiendo en el mismo lecho. Se dijo incluso que Salvador le había pegado a su ama una gaznatada al parecer por causa de los celos. Varios testimonios señalaban también que por las noches la cuestionada pareja solía apartar premeditadamente a la esposa esclava de dicho negro, quedándose él en la casa con su señora, y que además doña María Antonia lo convencía para que no se viera con su mujer ni le entregara lo que le correspondía por concepto de sostenimiento. Según los rumores, estos perjuicios y abandonos reiterados habían llevado a esta esclava traicionada a la sepultura.

Se ordenó entonces poner en depósito a doña María Antonia en la casa de don Juan Bernardo de Villa mientras que el concubino fue reducido a cárcel. Al ser interrogada por los señalamientos referidos, ella negó tener amores con su hombre de servicio, aunque reconoció que trabajaba junto con él para conseguir 
su diario sustento y el de sus hijos y tres esclavos pequeños que le dejó en herencia su difunto marido. Esta dama atribuía todas estas denuncias a mentiras infundadas y habladurías que solo tenían como propósito manchar su honor y su buena reputación. No dudó en calificar al alcalde del partido de Miranda y al resto de testigos como hombres de "ínfima esfera" y "pobres necesitados", culpándolos de haber levantado la sumaria con el ánimo de conspirar en su contra, pues todo se había originado de los insultos y el ánimo de venganza de su propio hermano. El esclavo sindicado se ratificó en los mismos términos que su señora, aclarando que ella le ayudaba en actividades rutinarias menores como la reparación de cercas, las labranzas y la recogida de la cosecha de cacao.

Vicente del Campillo, fiscal nombrado para esta causa criminal, acusó al par de reos de haber ofendido a "ambas Majestades" con su "escandaloso" concubinato que se veía agravado con el adulterio cometido por el esclavo. Además de estos cargos, la pareja fue acusada de perjurio por haber mantenido oculta su relación. Por todos estos motivos, el fiscal pidió aplicar las más severas penas sin ningún tipo de indulgencias, decretándose el embargo de los bienes de la ama y al esclavo la condena de destierro luego de que cumpliera la "pena corporal".

Aunque los sindicados presentaron sus respectivos testigos, estas declaraciones no fueron suficientes para que el fiscal cambiara de parecer, sino que por el contrario le sirvieron para corroborar la cercanía de ambos en cuestiones laborales y quehaceres cotidianos. Doña María Antonia insistía en que en los testimonios que la culpaban no había ninguna afirmación tajante que indicara haberlos visto o sorprendido en escenas íntimas comprometedoras. Entre tanto, el procurador defensor del esclavo pidió que este negro saliera de la prisión debido a las penalidades que allí estaba experimentando.

En su fallo del 31 de octubre de 1803, el gobernador de la provincia de Antioquia decidió librar de la cárcel a los acusados. Doña María Antonia quedó absuelta del proceso pero, con el fin de evitar cualquier sospecha, se le ordenó que en un plazo no mayor de 15 días debía vender su negro, además de ser obligada a sufragar las costas del proceso. Y aunque la propietaria quedó satisfecha con el fallo que la eximía de la prisión, por otro lado expresó su inconformismo ante la orden de vender su negro y pagar las costas del proceso. Según ella, padecería un gran detrimento si no contaba con la mano de obra de su hombre de servicio, pues eso significaría la ruina de su estancia y el perjuicio para la manutención de su hogar. Adujo ser una señora de avanzada edad, dos veces viuda y agobiada por varias deudas a las que se le sumaban ahora los 60 patacones que había gastado en las diligencias y trámites del juicio. Consideraba esta mujer que era su hermano Ventura y el alcalde los que debían asumir el pago del proceso, pues eran ellos los que habían levantado falsas imputaciones. Finalmente, el teniente gobernador no 
halló méritos para atender la réplica de la propietaria y en consecuencia ella debió pagar 17 castellanos y un tomín por las costas del proceso (Archivo Histórico de Antioquia, tomo 38, legajo B98 1800-1810, ff. 1r-38v).

Este tipo de tramas, en la cual la involucrada sentimental era una viuda, pudo no ser tan extraña en la sociedad colonial si se tiene en cuenta el hecho de que las mujeres solían casarse con hombres mayores, lo cual hacía que en la pareja masculina fuera más temprana la mortalidad quedando las viudas en edad relativamente joven y en disposición de rehacer su vida sentimental (Bermúdez 83). Con bastante frecuencia las viudas quedaban como responsables del hogar y, por ello, era usual que aquellas no tan acomodadas exploraran una nueva compañía incluso más joven (Rodríguez 132) que pudiera no solo brindarle cariño, sino también colaborarle en materia de supervivencia económica sin necesidad de pensar en formalizar la relación a través del matrimonio.

Las represalias violentas derivadas de este tipo de enredos sentimentales pudieron desembocar en consecuencias mucho más funestas que las ya descritas. En una situación acaecida en la provincia de Girón hacia el año de 1711, don Pedro Girón fue asesinado por su esposa en asocio con su esclavo, por líos amorosos entre estos dos últimos. Los acusados fueron sentenciados a garrote hasta que naturalmente murieran por este castigo. Con este suplicio se quiso sentar precedente sobre lo inapropiado de este tipo de relaciones ilegítimas (Valderrama 39).

\section{CONCLUSIONES}

Sin duda, la vida afectiva y familiar de la población esclava fue muy compleja y dependió de la conjugación de una multiplicidad de factores. Continuamente, este segmento social se vio amenazado por disposiciones que coartaban la libre elección de pareja y sintió inhibidas sus posibilidades de desarrollo conyugal y familiar tanto en sus relaciones intraetnia ${ }^{9}$ como en sus aventuras pasionales con otros grupos étnicos. Solo en las fugas, en los palenques y en todos aquellos espacios de vida clandestina, se puede decir que el elemento negro contó con algún margen de libertad para unir su vida sin las habituales restricciones que le imponían su amo, el gobierno colonial y la Iglesia. Fueron varias las limitaciones padecidas por este segmento de la población en su intento

9 Sobre esta temática en particular, véase: Pita, "La esclavitud" 651-685. 
por construir una vida afectiva. Fue, en muchos aspectos, un desalentador ingrediente dentro de su ya azarosa vida cotidiana.

En particular, los casos descritos dejan al descubierto las inmensas complicaciones que debió afrontar el elemento esclavo en sus relaciones amorosas con integrantes de otras etnias, una situación en la cual las variables de género, raza y estatus fueron realmente determinantes en medio de una sociedad tradicionalmente patriarcal y fuertemente permeada por los principios morales pregonados por el catolicismo. Muy evidente era el estado de indefensión de las esclavas y los esclavos ante sus amos y ante la justicia.

Dentro del espectro de relaciones afectivas entre blancos y esclavas, los casos referidos en este artículo fueron sin duda percibidos como máximas transgresiones al orden social y a la normatividad vigente en relación con el matrimonio intraétnico y las uniones legales. Eran hechos que suscitaron escándalos y fuertes reproches por parte de la Iglesia y de las autoridades españolas, pero que de alguna manera ponían de presente el ímpetu de las pasiones que trascendían más allá de los convencionalismos y restricciones de la época.

Aún con todas las dificultades, resulta realmente destacable el valor y la decisión con que la comunidad esclava buscó reivindicar sus derechos sociales y sentimentales. Sin duda, las historias incluidas en este artículo conllevan a cuestionar el imaginario que la historia tradicional ha elaborado sobre el esclavo como un ser sumiso y pasivo. Por el contrario, tal como reitera también en su estudio la historiadora Juliana González Fernández, lo que queda al descubierto en los expedientes revisados es que estos individuos en estado de esclavitud, en una actitud desafiante, lograron tomar acciones y decisiones por sí mismos en busca de expresar y hacer valer sus pasiones (González, Seducción 47). En ese sentido, ellos encontraron en los litigios una forma estratégica de ser atendidos sus clamores y de lograr ciertas concesiones sustentadas en la legislación imperante (Sherwin 32).

En materia judicial, quedaban en evidencia los contrastes, pues muy pocas veces los propietarios recibían condenas proporcionales a la magnitud de sus excesos, mientras que los integrantes de la comunidad esclava debieron padecer destierros y encarcelamientos. Resulta además muy dramático en los casos aquí revisados los altos índices de violencia y maltrato hacia los esclavos como reacción ante este tipo de líos pasionales.

En varios casos, fueron muy notorias las alianzas entre los amos y las autoridades locales por pertenecer ambas partes a la misma esfera social y de poder, situación que obligó a las esclavas y a los esclavos a recurrir a instancias superiores en busca de mayor imparcialidad y pronta administración de justicia. 
Otro factor que perturbó el desarrollo de los juicios fue la insistente oposición de la familia de los amos que recurrían a todo tipo de artificios con el fin de torpedear las acciones adelantadas por los esclavos en su aspiración porque se les reconociera su libertad y otros derechos adquiridos como producto de sus "ilícitos" amoríos. A fin de cuentas, buena parte de las relaciones amorosas aquí reseñadas terminaban en separaciones definitivas con la desesperanza de que en muchos casos jamás volverían a encontrarse.

\section{REFERENCIAS BIBLIOGRÁFICAS}

Archivo General de la Nación. Bogotá, Colombia. Sección Colonia, Fondos: Criminales, Negros y Esclavos.

Archivo Histórico Cipriano Rodríguez Santa María-Universidad de La Sabana. Bogotá, Colombia. Fondo Manuel María Mosquera.

Archivo Histórico de Antioquia. Medellín, Colombia. Sección Antioquia, Fondo Colonia, Grupo Negros y Esclavos.

Archivo Histórico de Cartago. Cartago, Colombia. Fondo Judicial-Colonia, Subfondo Alcalde Ordinario.

Archivo Histórico Judicial de Medellín. Medellín, Colombia. Fondo Criminal.

\section{Bibliografía}

Bermúdez, Suzy. Hijas, esposas y amantes. Género, clase, etnia y edad en las historia de América Latina. Ediciones Uniandes, 1992.

Dueñas Vargas, Guiomar. Los hijos del pecado: ilegitimidad y vida familiar en la Santafé de Bogotá colonial. Editorial Universidad Nacional de Colombia, 1997. https://doi.org/10.2307/1008446

Castillo Palma, Norma Angélica. "Matrimonios mixtos y cruce de la barrera de color como vías para el mestizaje de la población negra y mulata (16741796)". Signos Históricos, vol. 2, no. 4, 2000, pp. 107-137. https://doi. org/10.22201/fi.25940732e.2002.03n4.018

Ericastilla Samayoa, Anna Carla y Lizeth Jiménez Chacón. “"A riesgo de perder el honor», Transgresiones sexuales de las mujeres en Quezaltenango Guatemala, siglo XIX”. Diálogos. Revista Electrónica de Historia, vol. 5, no. 1-2, 2005, pp. 2-24. https://doi.org/10.15517/dre.v5i1-2.6239

Escalante, Aquiles. El negro en Colombia. Universidad Nacional, 1964.

Foucault, Michel. "Prefacio a la transgresión". Obras esenciales. Paidós, 2010, pp. 146-158. 
Gonzalbo Aizpuru, Pilar. Familia y orden colonial. El Colegio de México, 1998. https://doi.org/10.1353/tam.2002.0125

González Fernández, Juliana. Seducción, ilegalidad y pasiones: las relaciones afectivas de los esclavos neogranadinos a finales de la Colonia. Tesis de pregrado, Pontificia Universidad Javeriana, 2010. https://doi. org/10.33304/revinv.v01n1-2013003

González, Luis. Otra invitación a la microhistoria. Fondo de Cultura Económica, 2000.

Grisanti, Ángel. El Precursor Neogranadino Vargas. Editorial Iqueima, 1951.

Gutiérrez Azopardo, Ildefonso. Historia del negro en Colombia. ¿Sumisión o rebeldia?, 4 ed. Editorial Nueva América, 1994.

Gutiérrez de Pineda, Virginia y Roberto Pineda Giraldo. Miscegenación y Cultura en la Colombia Colonial 1750-1810. Tomo II, Ediciones Uniandes, 1999. https://doi.org/10.1017/s0022216x00005174

Gutiérrez de Pineda, Virginia. La Familia en Colombia: trasfondo histórico. Editorial de la Universidad de Antioquia, 1997.

Guzmán, Florencia. Los claroscuros del mestizaje. Negros, indios y castas en la Catamarca colonial. Encuentro Grupo Editor, 2010.

Helg, Aline. "Sociedad y raza en Cartagena a fines del siglo XVIII". Cartagena de Indias en el siglo XVIII, editado por Haroldo Calvo Stevenson y Adolfo Meisel Roca, Banco de la República, 2005, pp. 319-364.

---. "La limpieza de sangre bajo las reformas borbónicas y su impacto en el Caribe neogranadino". Boletín de Historia y Antigüedades, vol. CI, no. 858, 2014, pp. 143-180. https://doi.org/10.32468/chee.42

Hering, Max y Nelson A. Rojas. Microhistorias de la transgresión. Universidad Nacional de Colombia-Universidad Cooperativa de ColombiaUniversidad del Rosario, 2015. https://doi.org/10.26512/hh.v4i8.10957

Jaramillo Uribe, Jaime. Ensayos de Historia Social. Tomo I, Tercer Mundo Editores, 1989. https://doi.org/10.7440/histcrit3.1990.12

Jaramillo Velásquez, Carolina. El matrimonio y las prácticas sexuales como estrategias de ascenso social de la población de castas. Medellín y su zona de influencia, 1776-1830, Tesis de Maestría, Universidad Nacional de Colombia, 2016. https://doi.org/10.15446/hys.n31.54258

Jiménez Meneses, Orián. "Los amos y los esclavos en el Medellín del s. XVIII". Historia y Sociedad, no. 5, 1998, pp. 119-133.

Konetzke, Richard. Colección de documentos para la historia de la formación social de Hispanoamérica. Vols. I y III, Consejo Superior de Investigaciones Científicas, 1958. https://doi.org/10.2307/979544 
Las Siete Partidas del Rey Don Alfonso El Sabio. Tomo II, Imprenta de Panckoucke, 1846. https://doi.org/10.36576/summa.7842

Lavrin, Asunción. "La sexualidad en el México colonial: un dilema para la Iglesia”. Sexualidad y matrimonio en la América Hispánica siglos XVIXVIII. Coordinadora Asunción Lavrin, Editorial Grijalbo, 1991. https:// doi.org/10.24275/uami.f7623c581

Man, Ronen. "La microhistoria como referente teórico-metodológico. Un recorrido por sus vertientes y debates conceptuales". Historia Actual Online, no. 30, 2013, pp. 167-173.

Mejía Espinosa, María Emilia. La preocupación por el honor en las causas judiciales seguidas por adulterio en la Nueva Granada entre 1760 y 1837. Tesis de pregrado, Universidad Colegio Mayor de Nuestra Señora del Rosario, 2011. https://doi.org/10.19053/20275137.3722

Mejía Velásquez, Karen. Esclavitudy libertad. Una aproximación a las dinámicas de manumisión de los esclavos y a la búsqueda de espacios independientes en la provincia de Antioquia, 1780-1830. Tesis de Maestría, Universidad Nacional de Colombia, 2016. https://doi.org/10.15446/historelo. v9n17.57540

Möllien, Gaspard-Théodore. Viaje por la República de Colombia en 1823. Colcultura, 1993.

Mosquera, Sergio. Memorias de los últimos esclavizadores en Citará. Historia Documental. Promotora Editorial de Autores Chocoanos, 1996.

Pacheco, Juan Manuel S. J. "Historia Eclesiástica". Historia Extensa de Colombia. Vol. XIII, tomo II, Editorial Lerner, 1986.

Patiño Millán, Beatriz. "Las mujeres y el crimen en la época colonial. El caso de la ciudad de Antioquia". Las mujeres en la historia de Colombia. Tomo II, Directora Magdala Velásquez Toro, Editorial Norma, 1995, pp. 77119. https://doi.org/10.18046/recs.i15.1937

Patiño, María Teresa. "Delitos en torno al núcleo familiar. Delitos contra las mujeres". Historia y Memoria, no. 5, 2012, pp. 179-200.

Patiño, Víctor Manuel. Historia de la cultura material en la América Equinoccial. Tomo VII. Instituto Caro y Cuervo, 1993.

Perera Díaz, Aisnara y María de los A. Meriño Fuentes. Esclavitud, familia y parroquia en Cuba: otra mirada desde la microhistoria. Editorial Oriente, 2008. https://doi.org/10.32997/2382-4794-vol.5-num.5/2013/382

Pita Pico, Roger. "El adoctrinamiento de esclavos en el nororiente neogranadino durante el período colonial". Boletín de Historia y Antigüedades, vol. XCI, no. 827, 2004, pp. 795-827. 
---. “«La "esclavitud» de los sentimientos: vida familiar y afectiva de la población esclava en el nororiente del Nuevo Reino de Granada, 17201819”. Revista de Indias, vol. LXXII, no. 256, 2012, pp. 651-685. https:// doi.org/10.3989/revindias.2012.21

Rebolledo Rebolledo, Raquel. "El amancebamiento como falta al sistema incipiente de disciplinamiento social: Talca en la segunda mitad del siglo XVIII". Atenea, no. 491, 2005, pp. 99-112. https://doi.org/10.4067/ s0718-04622005000100008

Rodríguez, Pablo. Sentimientos y vida familiar en el Nuevo Reino de Granada. Editorial Ariel, 1997. https://doi.org/10.1353/tam.2002.0059

Romero Jaramillo, Dolcey. Esclavitud en la Provincia de Santa Marta 17911851. Instituto de Cultura y Turismo del Magdalena, 1997. https://doi. org/10.2307/j.ctt1zgwmtf.7

Roncancio Parra, Nelson Andrés. "Los disentimientos matrimoniales en la villa de Nuestra Señora de la Candelaria de Medellín en el siglo XVIII". Nobles, blancos y mestizos en la villa de Nuestra Señora de la Candelaria de Medellín. Probanzas de Nobleza, familia y mestizaje del cabildo 1674-1812, Tomo II, compilador William Jaramillo Mejía, Instituto Colombiano de Antropología e Historia, 2000, pp. 483-505. https://doi. org/10.3989/hs.2013.039

Saco, José Antonio. Historia de la esclavitud de la raza africana en el Nuevo Mundo y en especial en los países américo-hispanos. Tomo III, Cultural S.A., 1938. https://doi.org/10.2307/2714695

Sherwin K., Bryant. "Enslaved Rebels, Fugitives and Litigants: The Resistance Continuum in Colonial Quito". Colonial Latin American Review, vol. 13, no. 1, 2004, pp. 7-46. https://doi.org/10.1080/1060916042000210800

Stella, Alessandro. "«Mezclándose carnalmente». Relaciones sociales, relaciones sexuales y mestizaje en Andalucía Occidental”. Negros, mulatos, zambaigos. Derroteros africanos en los mundos ibéricos. Coordinadores Berta Ares Queija y Alessandro Stella, Escuela de Estudios Hispano-americanos, 2000, pp. 175-188. https://doi.org/10.1017/ s0395264900004625

Tieghi, Osvaldo. Delitos sexuales. Tomo I, Editorial Ábaco de Rodolfo Depalma, 1983.

Tovar Pinzón, Hermes. Convocatoria al poder del Número. Archivo General de la Nación, 1994.

---. La batalla de los sentidos. Infidelidad, adulterio y concubinato a fines de la Colonia. Universidad deLosAndes, 2012.https://doi.org/10.7440/2013.41 
Twinam, Ann. "Honor, sexualidad e ilegitimidad en la Hispanoamérica colonial". Sexualidad y matrimonio en la América Hispánica siglos XVI-XVIII, coordinadora Asunción Lavrin, Editorial Grijalbo, 1991, pp. 127-160. https://doi.org/10.4000/books.ifea.4496

---. Vidas públicas, secretos privados. Género, honor, sexualidad e ilegitimidad en la Hispanoamérica colonial. Fondo de Cultura Económica, 2009.

Valderrama Benítez, Ernesto. Real de Minas de Bucaramanga. Imprenta de Santander, 1947. https://doi.org/10.18273/revsal.v49n2-2017003

Wade, Peter. Gente negra, nación mestiza: las dinámicas de las identidades raciales en Colombia. Siglo del Hombre Editores-Ediciones Uniandes, 1997. 